Central Washington University

ScholarWorks@CWU

All Master's Theses

Master's Theses

1956

\title{
A Survey of the High School Course in Physical Science
}

Kenneth $\mathrm{H}$. Johnson

Central Washington University

Follow this and additional works at: https://digitalcommons.cwu.edu/etd

Part of the Educational Assessment, Evaluation, and Research Commons, Science and Mathematics Education Commons, and the Secondary Education and Teaching Commons

\section{Recommended Citation}

Johnson, Kenneth H., "A Survey of the High School Course in Physical Science" (1956). All Master's Theses. 1031.

https://digitalcommons.cwu.edu/etd/1031

This Thesis is brought to you for free and open access by the Master's Theses at ScholarWorks@CWU. It has been accepted for inclusion in All Master's Theses by an authorized administrator of ScholarWorks@CWU. For more information, please contact scholarworks@cwu.edu. 


\author{
A SURVEY \\ OF THE HIGH SCHOOL COURSE
}

IN PHYSICAL SCIENCE

A Thesis

Presented to

the Graduate Faculty

Central Washington College of Education

\author{
In Partial Fulfiliment \\ of the Requirements for the Degree \\ Master of Education
}

by

Kenneth H. Johnson

August 1956 
$\angle D$

57713

J 675

들

$!$

82531 
APPROVED FOR THE GRADUATE FACULTY

W. W. Newschwander, COMMITTEE CHAIRMAN

E. L. Muzzall

B. E. Michals 
TO MY WIFE, PAT

FOR HER

INCOURAGEMENT AND ASSISTANCE 
The writer wishes to acknowledge his indebtedness to all those who have contributed in any way to the writing of this thesis; especially to the committee chairman, Dr. Newschwander, who took the time to help stimulate and clarify the thinking that went into this study. 
I. THE PROBLEM AND LIMITATIONS OF

THE STUDY • • • • • • • • • • • • • 1

The problem . . . . . . . . . . . . 1

Statement of the problem . . . . . . . 1

Importance of the study..$\quad$ - . . - . 2

Methods and procedures . . . . . . . 3

Limitations of the study. . . . . . . . . 4

II. HISTORY AND DESCRIPTION OF THE COURSE

IN PHYSICAL SCIENCE. • • • • • • • • 5

Introductory material . . . . . . . . $\quad 5$

A brief history of the course . . . . . . 7

A description of the course.$\quad$. . . . $\quad$ - 9

The characteristics of the course . - . 9

The objectives of the course . . . . . 12

The course content . . . . . . . . 14

III. THE QUESTIONNAIRE AND SURVEY • • • • • 19

The questionnaire. • . . . . . . . 19

The gurvey . • . . . . . . . . . . 21

IV. THE FINDINGS OF THE SURVEY • • • • • • 26 
The characteristics, content, function, and place of the courae in physical science - . 28 The characteristics and content of the course • • • • • • • • . . . . . 28

The function and place of the courge . . . 37 Some current practices used in teaching the course in physical science. . . . . . . 41 Materials used in teaching the course. . . 43 Activities used in teaching the course . . . 56 Some additional practices used in teaching the courae - • . - . . . . . . . 67

The values and limitations of the course in physical meience . . . . . - . . . 74 The college acceptance of the course. . . 74 Reasons for the schools having discontinued the course . . . . . . - . . . . 76

Comments written in regard to the course . 77 V. THE SUMMARY AND CONCLUSIONS • . . . $\quad 85$ The summary - • • - • - • - • - • 86

The characteristics, content, function, and place of the course . . . . . . 86 Current practices used in teaching the 
The values and limitations of the course . .

BIBLIOGRA PHY

APPENDICES .

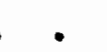

$\cdot \cdot$

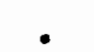

$\cdot \cdot$

$\cdot \cdot$

99

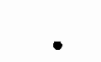

APPENDIX A. The Questionnaire.

APPENDIX B. The Letter Which Accompanied

the Questionnaire.

111

APPENDIX C. The Reminder Card .

113 


\section{LIST OF TABLES}

TABLE

I. Distribution of the Survey by States. . . . .

II. Classification, Number, and Per Cent of Those Responding to the Survey . . . . . . . . 24

III. The Sizes and Types of the Schools in the Survey . 27

IV. Positions of Persons Completing the Questionnaires . . . . . . . . . . . . •

V. Grade Level Placements of the Course in

Physical Science • . . . . . . . .

VI. The Years in which the Course in Physical Science

Was Fir st Taught, and the Number of Schools which Indicated Each Year. . . . . . .

VII. Titles Used for the Courses in Physical Science and the Number of Schools Using Each Title . .

VIII. The Responses and the Number of Schools

Responding to Each Question Concerning the

Function of the Course in Phyeical Science . .

Ix. The Three Functions of the Course Related to the Required and Slow Learner Aspects. . . . 
X. The Textbooks and Combinatione of Textbooks and the Number of Schools Using Each for Teaching the Course in Phystcal Sclence . .

XI. The Number of Schools Using Multiple Textbookg and Supplementary Reading Materials, and Combinations of These . . . . . . .

XII Titles, Types and Source of Films and Film

Strips Found Moat Valuable in Teaching

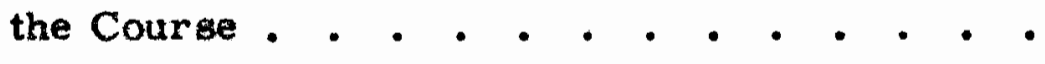

XIII. The Types of Laboratory Work, Their

Combinations, and the Number of Schools

Using Each in Teaching the Course in

Physical Sclence - . . . . . . . .

XIV. The Responses Concerning the Number of Fleld

Trips Taken in Conjunction with the Course

in Physical Science. . . . . . . .

XV. Field Trips Considered Most Valuable by the Persons Teaching the Course in Physical Science - . . . . . . . . . . .

XVI. The Responses Concerning the Number of Resource Persons Invited to Class for the 
TABLE

PAGE

Course in Physical Science . . . . . .

63

XVII. The Resource Persons Considered Most Valuable

by the Persons Teaching the Course in

Physical Science - . . . . . . . . 


\section{LIST OF FIGURES}

FIGURE

PAGE

1. Percentage of Time Spent on Each of the Five

Physical Science Subject Areas . . . . . 36 


\section{CHAPTER I}

\section{THE PROBLEN AND LINITATIONS OF THE STUDY}

The traditional science prograis taught in most secondacy schools today has been subject to criticlem frorn both cducators and laymen. The growing recontion of the inadequacy of the progran hag bean expreged through the development of numerous new courses to enrich the science curriculum. One of the more recent additions to the currtculus has been the high school course In phystcal science--a course which was intended to be in keepin with the current trend of emphasis on seneral education. Although the course at present has no standard body of subject matter, as heve the pure chemistry and pinysics courses, it has basically been patternad after the high achool course in general biology. Therefore, all the phystcal sclences-phystes, chemistry, geology and physical geography, astronomy, and meteorology-may be intecrated tnto the course of atudy. Many believe that such an integrated course may better fulfill the requiremente of a greneral education.

\section{THE PRCBL.N2}

Stutement of the problem. It was the purpose of this study 
(1) to determine the predominant characteriatica, content, functions, and place of the High School course in phystcal science in relation to the over-all science program, (2) to disclose some of the current practices found to be nost applicable to the course, and (3) to deterraine the most Important values and limitations of the course as it has currently been taught.

Importance of the study. The growing belief of the need for improvement and reorganization of the becondary school sctence curriculum has stimulated far-sighted educators into moulfying the traditlonal program. Many now courses have bean developed, but there has been a need for more knowledge of these improvements and for further research into the nature of each course. Most of the Information avallable on the course in phyatcal sctence has been theoretical in nature and has not pertalned drectly to current practices actually being used by those who teach the course. The regults of this survey may be of some help to (1) administrators and supervisors who are considering the course in physical sctence as an addition to their present science program, (2) teachere in the field who may be expected to teach the course in the future, and (3) teachers in training who wh to prepare themselves for teaching this course. 
Methods and procedures. In order to locate schools throughout the country teaching the course in physical science a list of four known publishers of high school phylcal science textbooks was complled from The Amarican Educational Catalog. A letter was sent to each publtsher explatining the purpose of this study and requesting a list of schools using their texts. A Bimllar letter was sent to elght other publisher believed to have possibly been publishing hlgh school physical science textbooks.

Anower were recelved from nine of the twelve publishers contacted. The weven repltes from the posstble publishers indicated that thetr physical science textbooks were used only by colleges or were out of print. Two of the known publiahers replted; one indtcated that the information requested was not avatlable, while the other. D. Van Nostrand Company, Inc., forwarded three listo of orders placed for their textbook Phyaical Sciences for High Schools. by Hogg. Cross, and Little. The lists were (1) from publication, 1951, through Auguat 15, 1952, (2) from August 15, 1952, through December 31, 1952, and (3) during 1953. They indicated that llats for 1954 and 1955 were not available.

A mailing list of $218 \mathrm{high}$ schools and 8 school districts from thirty-four states and the Digtrict of Columbia was complled from the above three lista. A questionnaire accompanied by a personal letter 
was maited to the head of the department of science of each of the $218 \mathrm{high}$ schools, and a letter with enclosed questionnaires and letters (the number of enclosures depended upon the stze of the city) was malled to the director of secondary education of each of the 9 school districts. It was requested that he forward the enclosed questionnaires and letters to the head of the separticent of science of sach of the schools in his district that presently taught or had in the past taught the course in physical welence.

\section{LIMTRATONS OF THE STUDY}

This study was limited to the course in physical science, Which was but one of the nany new courses developed to enrich the secondary school sctence program. The survey did not include schools teaching the courge without the ald of a standard textbook: schoola using textbooks which ware secured from ances other than the one covered by this study; or achools which way have begun teaching the course in the shool yeard 1954-55 or 1855-56. 


\section{CHAPTER II}

\section{HISTORY AND DESCRIPTION \\ OF THE COURSE IN PHYSICAL SCIENCE}

The exact function of the course in physical science has yet to be determined. It has been felt by mome that it should be a fusion of chemistry and physics, and function as a substitute for these courses. This point of view expressed by Peterson in the following otatement: "It was Intended that the new courae retain the vigor of the better chemistry and physics courses and include the most important concepts common to both fields. "1 Others have felt that the course might Include all the physical sciences and function as atep th the sequence of sclence coures to provide a background for further otudy in chemistry and physfcs. This has been accoraplished by substtuting the course in physical science for geaeral science and teaching general sclence in lower grades. ${ }^{2}$ Still others have felt that the course ohould function as a general

IShailer Peterson, "The Evaluation of a One-Year Course, The Fuston of Physics and Chemistry, with Other Physical Sclence Courses," Sclence Education, 29:255, December, 1945.

${ }^{2}$ Nelson L. Lowry, "Blology and Phyelcal Science for Ninthand-Tenth-Grade Studenta," Sclence Education, 35:71, March, 1951. 
education course for atudents whose secondary education to terminal or for non-science college preparatory studente. Two administrators have exprassed thi view as follows:

We have one course for those who intend to major in the subject, and who have a liking for It, together with a natural talent; and another [1.e.. physical sclence] for thoee who with a beginning course for general oducation purposes. 3

A problem of great concern in the development of a new course has been the wllingnes of the institutions of higher learning to accept the course for college entrance. It was felt by some that the trend has been to accept those courses the high schools have designated as college preparatory. 4 The Forty-Sturth Yearbook of the National Society for the Study of Education Indicated that colleges were generally willing to recognize the physical actence course as a bona-flde college entrance unit for the non-science major. ${ }^{5}$ In 1945 , Carleton surveyed ninety-five colleges concerning their willingness

3G. L. Ratrick and John G. Read, "Criteria for Evaluating a Secondary School Sctence Program," Educational Adminiatration and Superviaion, 36:312, May, 1950.

${ }^{4}$ Robert H. Carleton, "The Acceptability of Physical Science as a College Entrance Unit," Sctence Education, 30:127-132, Aprtl, 1946.

5"The Course in Physical Science," Sctence Education in American Schools. Forty-Sixth Yearbook of the National Soctety for the Study of Education, Part I (Chtcago, Illinols: Univereity of Chlcago Preas, 1947), p. 191. 
to accredit such courses; of the seventy-six colleges responding to his survey, none refused to approve them. In conclusion, Carleton stated that:

Colleges are more incitned to be liberal in the nature and variety of secondary-school courses which they will accept as entrance units than many secondary-school teachera, counselors, and administrators give them credit for. ${ }^{6}$

\section{A BRIEF HISTORY OF THE COURSE}

Although the high school course in physlcal sclence has generally been considered a new development. Its history dates back at least to the $1930^{\prime} \mathrm{s}$. Even before, many general science courses were orlented around phyolcal sclence matertal, particularly if the teacher's preparation includted only the phyalcal sciences. Research studies relating to physical science in general education go back as far as 1833 when Wray attempted to determine what Items of chemical information would be rated high in functional value by non-science speclalists. ${ }^{7}$ The 1937 report of the Committee on the Function of Science in General Education included an article by Tenney deecribing his eleventh grade fused physical

\footnotetext{
${ }^{6}$ Carleton, op. cit., p. 131.

7"The Course in Physical Science," op. c1t., p. 194.
} 
sctence course, 8 and in 1939 Brown published an article describing the development of a course in physical science. 9 Hunter and Spore reported that in 1938-39 over geven thouband high school students were enrolled in phystcal science coirses in California alone. 10 By 1940 Watson reported that the high schools of fiftyfour citieg of over 25,000 population, in twenty-stx states, offered phystcal science courses. During World War II, physical sclence courses were temporarily replaced by war oriented courses. 11 Johnson, in 1947-48, studied a "etratfied random sample" of 755 of the 23,947 public high schoole. He found only seven schools teaching courses in physical acience; however, he noted that 61 of the 135 high schools offering sclence courgee other than general sctence, biology, chemistry, and physics included courses of the physical acience type. 12 He further stated:

A Asa C. Tenney. "A Fused Physical-Science Course," Science in General Education, Heport of the Committee on the Function of Science in General Education (New York: Appleton-Century. 1938), pp. 477-500.

${ }^{9}$ H. Emmett Brown, The Development of a Course in the Physical Sctences for the Lincoln School (New York: Teachers College, Eureau of Publications, 1939).

10"'The Course in Phystcal Science," op. cit. . p. 190. Iibid.

${ }^{12}$ Phillp G. Johnson, The Teaching of Sctence in Public tyigh Schools, Federal Security Agency, Office of Education, Bulletin No. 9 (Washington: Government Printing Office, 1950). 
The more numerous offerings of additional or alternate sctence couraes of the physical aclence type may Indicate that schools were searching for science offerings to intereat pupils who did not elect the usual chemistry and phyatca couraes. 13

The United States Ofice of Education reported that in the 1848-49 school year over seven thousand students were enrolled in physical Bcience course offered in twenty one states. 14 The authors of a current college textbook on science education summarized the present atate of the course af follows:

The newer course in general phyaical gclence seems at present to have broken away from the objectives of physics and chemistry. In most places the course 18 taught for the values that it has for aiding young people In the adfugtment to life problems. Another interesting trend in some of the courses in phystcal sctence ts the emphasis placed on training in the abilities of problemcolving and in the development of desirable attitudes. 15

\section{I1. DESCRIPTION OF THE COURSE}

The characteristice of the courge. In regard to the phyeical

$13_{\text {Ibld. . p. } 22 .}$

${ }^{14}$ Phillp $\mathrm{G}$. Johneon, "Occurrence of Sclence Courees in American High Schools, "The Bulletin of the National Assoctation of Secondary-School Principate, 37:23, January, 1953.

15. Llwood D. Heles, Ellaworth S. Oboum, and Charles W. Hoffman, Modern Sclence Teaching (New York: Macmillan Company. 1850), p. 24 . 
characteristics, a recent wurvey indlcated that the physical science courae has been generally designed for full year's duration, with less than five per cent destgned for one semeater. ${ }^{16}$ A few were planned a. two-year courses; the first year was devoted to general physical sclence and the second year to a semester of chemintry and a semester of physlcs. 17 The two-year courne unually appeared in the eleventh and twelfth grades. The shorter courae was occaslonally offered in the ninth grade, but wes bastcally destgned for tenth, eleventh, or twelfh gracle students.

One of the more Important characteriatic has been the absence of standard course of study. This hes been considered by some educator as more of a boon than a detriment to the conecientlous actence teacher. The Forty-Sixth Yearbook of the Nattonal Soctety for the Study of Education emphasized this point by stattig:

He is thus free to negotiate, explore, and experiment, to start with the interests and problems of his own puplls, and to draw on his own community for source materials without betng hampered by the old bugaboo (real or tmagined) of having to "cover" co much "ground" or of having to prepare his puplis to rocet the demande of certain eatablished examinations. He ts at liberty to select and organize hts own

${ }^{16}$ Brown, "Trendw in Kigh School Courses in Integrated Phyaical Sctence," op. clt.. p. 86.

17 bid. 
content of eubject matter and activities in terme of his own reasoned philosophy. He can, of course, get some help in this tack by reviewing the relatively fow published research etudtea relating to phyolcal sclence in general education. 18

Another characterietic of the course has been the emphaale on general education. The Harvard Report stated that, "Sclence inetruction in general education should be charactertaed by broad Integrative elemente. . ." It further stated that the course in phyotcal sclence should ". . be a otematic presentation of concepte and principles of the phystcal sclences. . . "10

This characteristic, whth all ite ramifications, was brought out by a committee atudying secondary education in the Pitteburgh schools. The committee felt that the phyatcal science course should be (1) for eleventh and twelfth grade students not golng on to college. (2) lesa formal than physice or cbemtatry, (3) more practical and Interpretive, (4) more dencriptive with many applications, (5) purposeful in developing underatanding of the materiale of civilization and indght into scientific principlee which contribute to good individual and community life adjustmenta, and (6) taught

18"The Course in Phyefcal Science," op. 스. . p. 192.

19pld. . p. 191, clting The Harvard Report, General Education in a Free Society. 
with more emphasis on attitudes of mind, methods of thinking and working, and the social implications of these methods. 20

The important characteristics of the course in physical

actence were oummarized by Heiss and hio ansociate as follows:

The course in physlcal aclence, judging by the inatructional materials selected by the authors of some textbooks, and by matertals proposed in certain courees of atudy, seemo to be much more functional than elther of the other spectalIzed physical sctences. The present situation regarding this newer course to much in a state of hux that it is difficult to ascertain what the trend for physics and chemistry chould be. There is a constderable tendency on the part of some in the field of secondary actence to belleve that the courses in phyoles and chemistry should be retained much in their present form but offered only to those pupils who plan to go on in some field of sclence as a profession. This would then leave the course in physical science to take care of the functional needs of the young people not interested in specializing in science. 21

The objectives of the couree. Many of the objectives of the course in physical sclence paralleled those for chemistry and phyatca. Others were much broader, thus renecting the emphasto on general education. The brondeat objectives attributed to the course were presented by Robinson in a study to determine if fused

20 John A. Hollinger, et al., "Physical Sclence in Senior High Schoole," Sclence Education, 28:130-131. April, 1944.

${ }^{21}$ Heies, Obourn, and Hotfman, op. cit. p. 69. 
science courses could ". . (1) ... foster the realization of pereonal potentlalities, and (2) ... help the individual function adequately an adherent and a contributor to the democratic way of life."22 The study included the (1) examining of textbooks to find toplcs and total number of times each topic appeared, (2) reviewing of newspapers and magazines read by atudents to acertain what subjecte were most frequently discussed, (3) reviewing of perfodicals and books to discover the point of view of leading educators, (4) holding of conferences with sclence teachers, and (5) Interviewing of out standing textbook authors. Conside ration was also given to local conditions and outcomes of personal experience. Derived from the survey were (1) a set of general objectives, (2) an underlying polnt of vie $w$, and (3) criteria for the selection of content.23

The general objectives were (1) the use of the scientific method In the solution of problems, (2) the carrying of eclentific principles or generalizations to the point of functional underatancting. (3) the development of a scientific attitude, and (4) the acquiring of a sense of value of the work of scientiats. The underlying polnt of view indicated the course (1) served the rank and file, (2) concermed

\footnotetext{
22 Myra G. Robineon, "The Contributione of a Fused Science Course to General Education," School Roview, 54:215, Apr11, 1948. 23 Ibld. . pp. 215-216.
} 
problems of living, and (9) contalned the fundamentals of the physical selences and integrated them so that they would be more meaningful to the student and would make clear to him how they are related. 24 The criteria for the selection of content will be considered later.

In an article for the Bulletin of the National Association of Secondary-School Principals, Brown, in reference to the objective of the course in physical science, summarized as follows:

The atated objectives of these courses, as they appear in the literature, often differ little fror: those listed for phy aics and chemietry. Thus we note: (1) an understanding of the batc laws of nature; and (2) use of the scientific method in problem solving. Not so commonly associated with the older courses are the objectives, (3) the solving of problem that arise in dally living in the buying of goods; and (4) acquiring a sense of value of the work of scientist 8.25

The course content. The course content, with all its diversty. may be eegregated into three categories: (1) those concerned matnly or wholly with phystcs and chemiatry, (2) those concerned mainly with phyatce, chemiatry, and astronomy, and (3) those concerned with all five phyaical sclences--physics.

\section{Ibia.}

${ }^{25}$ Brown, "Trends in High School Courses in Integrated Phystcal Sctence," 오. clt.. p. 35 . 
chemistry, geology and physical geography, astronomy, and meteorology. 26 An example of the first type would be the outline suggested by Peterson: (Note the functional use of the sclence content.)

1. Introduction.

2. How Can Comfort Be Increased by Air Conditioning?

3. How Does Sclence Improve Our Homes and Office Butldings?

4. How Does Water Control Our Way of Living?

5. What Should Wo Look For When Buying An Automoblle?

6. How Do We Obtain Our Gasoline?

7. Do We Obtain Food and Poison from the stame Moleculea?

8. Will Plastics and the New Synthetic Textlle Make Nations Independent?

9. How Do We Obtain the Moot Valuable Metals?

10. What's Wrong with This Plcture?

11. What Has Sctence Done for Communication?

12. What is There Left to Invent and Discover? 27

An example of the second type would be the outline designed by Lowry and his assoclates:

1. Introduction (2 weeks)

2. Solar System (3 wooks)

3. States of Matter (2 weeks)

4. Energy (2 weeks)

5. Phystcs (15 weeks)
a. Forces
b. Force and Motion

${ }^{26}$ mid. , p. 86.

27 peterson, op. cit. p. 256. 
*. Work, Energ, and Power

d. Sound

e. Light

1. Electricity

6. Chemistry (12 weeks)

a. Themical Change

b. Nature of Chemical Proceses

c. Solutions

d. Non-metals and Compounde

- Organic Chemiatry

f. Uaeful Metals 28

Examples of the third type would be found in two of the most popular physical science textbooke in use today; note the many elmilartites. The frat outline was taken from Phy teal Sctence For High Schoole, by Hogi, Crose, and Little.

Introduction, Sclence and Iuman Achtevernent

Unit 1. The Nature of Things

Unit 2. The Earth

Unit 3. Temperature and Heat

Unit 4. Weather

Ualt 5. Fire and Fuels

Unit 6. Power From Combustion

Untt 7. Electrielty

Unit 8. Light

Unit 0. Communication

Untt 10. Structural Materials

Unit 11. The Universe 29

The decond was taken from Modem Payolcal Sclence, by Brooks and

${ }^{28}$ Lowry, loc. eit.

28 John C. Hoga, Judson B. Cross, and Elbert F. Little, Physical Sctences lor High Schools (New York: D. Van Noetrand Company, Inc.. 1851), p. ví. 
Tracy.

$$
\begin{aligned}
& \text { Unit 1. Air } \\
& \text { Unit 2. Water } \\
& \text { Unit 3. Fuele } \\
& \text { Unit 4. Forces } \\
& \text { Unit 3. Chemicals } \\
& \text { Unit 6. Metals } \\
& \text { Unit 7. Plastics } \\
& \text { Unit 8. Textlles } \\
& \text { Unit } 9 \text {. Health } \\
& \text { Unit 10. Sound } \\
& \text { Unit 11. Llght } \\
& \text { Unit 12. Electrielty } \\
& \text { Unit 13. Electronics } \\
& \text { Unit 14. Atomic Enercy } \\
& \text { Unit 15. Eerth Sclence } \\
& \text { Unit 16. Astronomy } 30
\end{aligned}
$$

The previously menttoned etudy by Robinson brought out

the following eight criteria for the selection of content:

a. Do the learning activitie make adequate provisions for pupll varfations in intereat and ablitty?

b. Is the content or ganised into problems which Illustrate man's quest for baslc values?

c. If the matertal so organixed that the pupil can readily assimtlate it into a developing framework of tunctional concepts?

d. Will the learning activitles help the otudent toward the realization of valld purposes, and will they help bim to apply selentific principles to new altuatione?

e. Does the content come from a rellable acurce, and does it belp the puptl to evaluate authority and to see how relative truth is ueed?

30 William O. Brooks and George R. Tracy, Modern Phystcal Sclence (New York: Henry Holt and Company, 1852), p. vil. 
P. Will the activities aelected provide an opportunity for the individual to do creative work and to experfence the joy, romance, and adventure that the successful accomplishment of creative work affords?

g. Is suffictent opportuntty provided to help the student fudge and measure his progrese toward the goals sought?

h. Is proviston made for aatiafying the etudent's intellectual curlosity? 31

Tenney eummed up the philosophy behind the selection

of content for the courge in physical seience when be stated:

Course content is found in the things, processes, ideas, and relationshipe with which young people are already in contact in the home and community and in anything in their total environment which bas made an impreasion on them. Half a dozen convenient centera are worked out for the organization of learning experiences. Beginning with the home, these extend outward through the community to the world, the treatment meanwhtle becoming more general as there is more and more colld basie for genervifing. 32

${ }^{31}$ Roblnøon, op. clt., p. 217.

32Tenney, op cil. p. 479. 


\section{CHAPTER III}

THE qUESTIONNAIRE AND SURVEY

The date for this survey were secured from a printed questionnalre sent to schools in thirty-four states and the District of Columbla belleved to be teaching the high school course in physical science. Each questionnaire was accompanied by letter addressed to the head of the department of science. The letter (1) briefly explained the purpose of this atudy, (2) noted that the survey included questions of general information and questions taken from sets of objectives for the teaching of high school science, and (3) requested cooperation in completing the questionnair as completely as possible and returning it in the enclosed self-addressed, stamped envelope.

\section{THE QUESTIONNAIRE}

The construction of the queationnaire consisted of the three followtng operations: (1) a master list of questions was complled; (2) the questions were valuated in terms of objectives for the teaching of high school sclence; and (3) the questions were revised, condensed, and edited to best suit the purposes of this study. The 
master list consisted of questions concerning all phases of the course in physical sclence. The list was complled after research into the literature on the course, intervitews with professors presently teaching the college course in physical sctence, and dlacubaions wth other teachers.

To gatn a broad baste for eveluating the course, many sets of objectives for the teaching of high school sctence were examined. They included objective set up by administrators, supervsors, and teachers. The following set by Grant, which appeared in the article "A High School Teacher Looke at Setence Education Objectives ${ }^{* 1}$ included those most frequently mentioned:

1. To develop skills in the classroom and laboratory

2. To meet the needs and interesta of puplis

3. To help puptle to acquire knowledge with an understanding of relationships and application to e veryday living.

4. To build aclentific vocabulary.

5. To develop attitudes and appreciations

6. To help puplls explore new flelds of interest

7. To discover aptitudes and abllities in puplls, and to direct these into useful channels

8. To develop sustained critical thinking and evaluation

9. To teach an unde rstanding of people and ways of working together

10. To help puplis formulate a phllosophy of life with wholesome and workable set of values

${ }^{1}$ Charlotte Grant, "A High School Teacher Looks at Sclence Education Objectives." The Bulletin of the National Assoctation of Secondary-School Principals. 37:16, January, 1953. 
It was then necessary to revise and condense the questions from the master list to beat suit the purposes of the study. The following suggestions by Bowley were used as guides to conatruct and edit the questions:

(1) They should be comparatively few in number: (2) it 18 better that they require an answer in terms of a number. or of a "yes" or "no": (9) they should be elmple enough to be readily underatood: (4) they should be formulated so as to avoid bias in answering: (5) they should not be impertinently or unduly inquisitional in character; (6) 80 far as possible. they should be corroboratory, or provide checks on each other as to accuracy: (7) and they should cover the points of information desired as directly and unmistakably as posatble. ${ }^{2}$

The question finally selected for the questlonnaire were designed to oscertain (1) pertinent data about the school, (2) current practice being used in the teaching of the courbe, and (3) the characterlatica, content, function, and place of the course in relation to the over-all sclence program.

\section{THE SURVEY}

The queationnaires for the eurvey were malled May 21, 1956, to 218 chools and 8 school districts. A reminder card to be sent two weeks from the ortginal malling date was then prepared. The card indicated that a response to the survey had not yet been received and that cooperation in completing and returning the questlonnatre as

2A.C. Bowley, Elements of Statistics (London: P. S. King and Company, 1920). p. 25 . 
soon ae posable wald be appreciated. On June 4,1956 , a liet of 140 schools and school districts not yet responding was complled and a reminder card was malled to each of these schools and districts on June 5,1956 .

Before tabulating the final survey, three schools and one whool district were dropped from the original list. The district returned all que gtionnairas sent to thens and stated that they would not be able to partlcipate in tha survey. Two wools, efter weeiving to reminder cards, Indicated that they had not received the questionnairas. One school, after recelving the reminder card, wrote that the repont had been completed and malled three days after it was recelved; but this completed questionnaire was neve: secelved here. As it was too late ta the school year to forward new questionnatre to these schools, they were dropped from the aurvey. The survey, therefore, included 214 schools and 7 school districts. Table I has been presented to show the distribution by states, and the number of schools returang que ationnatres.

As shown in Table 11,99 schools and 5 diatricts responded to the survey. Of this total, 73 schools and 3 districts werepresently teaching the high school course in phyatcal science, 17 schools and one district had never taught the course, and 8 schoob and on dist ict had oftered the coured in the past but were not presently teaching it. 
TABLE: I

DISTRIBUTION OF THE SURVEX BY STATES

\begin{tabular}{|c|c|c|c|c|}
\hline \multirow[t]{2}{*}{ STATES } & \multicolumn{2}{|c|}{ SCHOOLS } & & DISTRICTS \\
\hline & Sent & Returned & Sent & Returned \\
\hline Arizona & 1 & 1 & & \\
\hline California & 7 & 3 & $i$ & \\
\hline Connecticut & 16 & 8 & & \\
\hline Delaware & 1 & & 1 & \\
\hline Washtington, D. C. & 2 & 2 & & \\
\hline Georgla & 1 & & & \\
\hline Illinots & 21 & 10 & & \\
\hline Indiana & 12 & 7 & 1 & 1 \\
\hline lowa & 1 & 1 & & \\
\hline Kansas & 1 & & & \\
\hline Kentucky & 1 & & & \\
\hline Louisiana & 1 & 1 & & \\
\hline Maine & 2 & 2 & & \\
\hline Maryland & $\mathbf{3}$ & & 1 & 1 \\
\hline Massachusetts & 22 & 11 & & \\
\hline Michigan & 10 & 5 & & \\
\hline Minne sota & 2 & & & \\
\hline Missourt & 5 & 4 & & \\
\hline Nebraska & 3 & & & \\
\hline New Hampehire & 2 & 1 & & \\
\hline New Jersey & 13 & 8 & & \\
\hline New York & 9 & 5 & & \\
\hline North Caroline & 3 & 2 & $\bullet$ & 1 \\
\hline Ohlo & 14 & 4 & & \\
\hline Pennaylvania & 31 & 9 & & \\
\hline Rhode Island & 3 & 3 & & \\
\hline South Ca rolina & 2 & 2 & & \\
\hline South Dakota & 1 & & & \\
\hline Tennessee & 1 & & & \\
\hline Utah & 2 & & 1 & 1 \\
\hline Vermont & 2 & 1 & & \\
\hline Vtrginia & 2 & 1 & 1 & 1 \\
\hline Washington & 1 & & & \\
\hline Wisconsin & 16 & 6 & & \\
\hline TOTAL & 214 & 98 & 7 & 5 \\
\hline
\end{tabular}


TABLE II

CLASSIPICATION, NUMBER, AND PER CENT

OF THOSE RISPONDING TO TUE SURVEY

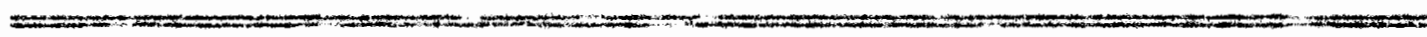

SCHOOLS DLSTICTS TOTAL

No. $\%$ No. $\%$

Those Who

Presently Teach

73

34

3

43

76

35

the Course

Those tho Have

Never Taught

17

8

1

$14 \quad 10$

8

the Course

Those tho Heve

Discontinued

8

4

114

8

4

the Course

Total

Re apondine

98

46

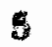

$72 \quad 103$

47

Total

Not

116

54

2

20

118

53

Responding

Total

surveyed

$214 \quad 100$

$7 \quad 100$

221

100 
25

As the schools and districts which have never taught the course in physical science contributed no significant material to the survey, they were not considered in the remainder of the study: nor was the one school district which responded by letter indicating that the course had been discontinued in the late thirties. The three school districts presently teaching the course returned a total of six questionnaires, making a total of seventy-nine school a presently teaching the course. The remainder of the study was organized from data received from the above seventy -nine schools and the eight schools which had taught the course in the past. 


\section{CHA PTER TV}

\section{THE FINDINGS OF THE SURVEY}

The data for the present study of the course in physical sclence were obtained from printed questionnaires recelved from 87 achools in twenty-four atates and the Diatrict of Columbia. The schools particlpating in the survey varied greatly in type. Five schools thught all 12 gradee (Bome also taught kindergarten); one school taught grades 4 through 12; ten schools taught grades 7 through 12; four taught grades 8 through $12 ;$ forty taught grades 9 through 12; and one school taught only grades 11 and 12. There was also considerable vartation in the size of the schools represented; two schools had enrollments of over 4,300 studenta, and, in contrast, one achool had an enrollment of only 85 students. The greateat number of schools had enrollments between 200 and 2,000 students. Table III shows a more detalled breakdown of the size of the schools and the grades taught according to the schoole which presently teach the course in phyatcal sctence and those which have discontinued the course.

The letter which accompenied each questionnatre was addressed to the head of the department of science with notation 
TABLE III

THE SIZES AND TYPES OF THE SCHOOLS IN THE SURVEY

Schools Presently Teaching the Course

\begin{tabular}{|c|c|c|c|c|c|c|c|}
\hline Enrollment: & $\begin{array}{l}1- \\
199\end{array}$ & $\begin{array}{l}200- \\
499\end{array}$ & $\begin{array}{l}500- \\
990\end{array}$ & $\begin{array}{l}1000- \\
1999\end{array}$ & $\begin{array}{c}2000 \\
\text { up }\end{array}$ & $\begin{array}{r}\text { Did } \\
\text { not } \\
\text { indi- } \\
\text { cate } \\
\end{array}$ & Total \\
\hline Grades $11-12$ & & & & 1 & & & 1 \\
\hline Grades $10-12$ & 1 & 4 & 5 & 11 & 2 & 1 & 24 \\
\hline Grades $9-12$ & 2 & 11 & 13 & 8 & 2 & 0 & 36 \\
\hline Grades $8-12$ & 0 & 0 & 1 & 0 & 1 & 1 & 3 \\
\hline Grades $7-12$ & 1 & 3 & 0 & 4 & 2 & 0 & 10 \\
\hline Grades $1-12$ & 0 & 1 & 0 & 0 & 3 & 1 & 5 \\
\hline Total & 4 & 19 & 19 & 24 & 10 & 3 & 79 \\
\hline
\end{tabular}

Schools Which Have Discontinued the Course

\begin{tabular}{|c|c|c|c|c|c|c|c|}
\hline Enrollment: & $1-$ & $\begin{array}{l}200- \\
499\end{array}$ & $\begin{array}{l}500- \\
999\end{array}$ & $\begin{array}{l}1000- \\
1999\end{array}$ & $\begin{array}{c}2000 \\
\text { up }\end{array}$ & $\begin{array}{r}\text { Did } \\
\text { not } \\
\text { indi- } \\
\text { cate } \\
\end{array}$ & Total \\
\hline $\begin{array}{cc}\text { Grades } & 10-12 \\
\text { Grades } & 9-12 \\
\text { Grades } & 8-12 \\
\text { Grades } & 4-12\end{array}$ & $\begin{array}{l}0 \\
1 \\
0 \\
1\end{array}$ & $\begin{array}{l}0 \\
0 \\
1 \\
0\end{array}$ & $\begin{array}{l}0 \\
2 \\
0 \\
0\end{array}$ & $\begin{array}{l}1 \\
0 \\
0 \\
0\end{array}$ & $\begin{array}{l}0 \\
0 \\
0 \\
0\end{array}$ & $\begin{array}{l}1 \\
1 \\
0 \\
0\end{array}$ & $\begin{array}{l}2 \\
4 \\
1 \\
1\end{array}$ \\
\hline Total & 2 & 1 & 2 & 1 & & 2 & 8 \\
\hline $\begin{array}{r}\text { Complete } \\
\text { Total }\end{array}$ & 6 & 20 & 21 & 25 & 10 & 5 & 87 \\
\hline
\end{tabular}


that he might fill it out or refer it to the person currently teaching the course. The questionnatre was completed in this manner, as Indicated in Table $T$, in all but six cases--three of which did not indicate the position of the person replying.

The remainder of the data for the survey were organized in relation to the purposes of the study. The purposes were as follows: (1) to determine the predominant characteri atics, content, function, and place of the course in physical science in relation to the over-all science program, (2) to disclose some of the current practice found to be most applicable to the course, and (3) to determine the most important values and limitations of the course as it has currently been taught.

I. THE CHARACTERISTICS, CONTENT, FUNCTION, AND PLACE OF THE COURSE IN PHYSICAL SCIENCE

The characteristics and content of the course. The findings of the survey generally supported what had been found in previous literature in regard to (1) the grade level for which the course was designed, (2) the duration of the courge, (3) the auspected increase in integrated physical science courses since World War II, and (4) the lack of a standard course of study. Sixty-two of the elghty-seven schools surveyed indicated that the course was designed 
TABLE IV

POSITIONS OF PERSONS COMPLETING THE QUESTIONNAIRES

Position Number Per Cent

Teacher

43

Head of the Science Department

35

Head of the Sclence Department and Teacher

3

City Supervisor of Science

2

Agsistant Professor of Science

1

Did not indicate

3

Total

87

100 
for eleventh and/or twelfth grade students. Table $V$ was included to show all of the grade level placements found in the survey. Physical science was taught as a full year course in all but four of the schools reeponding, although a few of these schools indicated that it could be taken for only one semester if so desired. One of the four exceptions was a school which offered physical science one semester and earth science the other semester. The second exception was a vocational school which offered a two-year course titled Trade Related Sciences which combined physics and chemistry. Two of the schools which had discontinued the course did not indicate the duration.

In answer to the question which asked what year the course was first taught, only ten schools indicated it hud first been taught during or prior to World War II. In contrast, twenty schools first taught the course in the years between the close of World War II and 1950, and thirty-nine schools began teaching the course in just the four-year period from 1950-51 through 1953-54. It was not a purpose of this study to establish a trend for the decrease or increase in the number of schools offering the course in physical science; in fact, it would have been impossible, due to the fact that the mailing list for the survey did not include schools believed to have first offered the course in the 1954-55 and 1955-56 school years. 


\section{TABLE V}

GRADE LEVEL PLACENIENTS

OF THE COURSE IN PHYSICAL SCIENCE

\begin{tabular}{lcc}
\hline Grade Level & $\begin{array}{c}\text { Number of Schools } \\
\text { Which Are Presently } \\
\text { Teaching Course }\end{array}$ & $\begin{array}{c}\text { Which Have Dis- } \\
\text { continued Courge }\end{array}$ \\
\hline 9th Grade & 3 & 1 \\
9th through 12th Gride & 4 & 1 \\
10th Grade & 5 & 2 \\
10th and 11th Grades & 5 & 1 \\
10th, 11th, and 12th Grades & 9 & 1 \\
11th Grade & 39 & 2 \\
11 th and 12th Grades & 11 & 8 \\
12 th Grade & 1 & 1 \\
Did Not Indicate & 79 & \\
\hline Total & & \\
\hline
\end{tabular}


However, it may be noted that the above figures, which were presented more completely in Table VI, did indicate an increasing growth of the number of schools offering the course in physical science in the post war years.

A list of fourteen titles being used for the course in physical science was complled from the questionnaires. "Physical Science" (or the similar title "Physical Science Survey") was indicated by forty-eight schools. The next most frequently indicated titles were "Senior Science," used by eight schools, and "Practical Science," used by six schools. The complete list of titles and the number of schools using them were shown in Table VII. One school had changed the title of their course this year, 1955-56, to "Earth Science." The new course of study stressed geology, physical geography, meteorology, and astronomy, but also included "some" chemistry and physics and was therefore included in the survey.

There was extreme diversity in the content of the courses surveyed. The schools were asked for the approximate percentage of time used to explore the five physical science subject areas and the answers ranged from zero to thirty per cent on astronomy, zero to forty per cent on chemistry, zero to eighty per cent on physics, zero to twenty-five per cent on meteorology, and zero to fifty per cent on geology and physical geography. In addition to the five mentioned 
TABLE VI

THE YEARS IN WHICH THE COURSE IN PHYSICAL SCIENCE

WAS FIRST TAUGHT, AND THE NUMBER OF

SCHOOLS WHICH INDICATED EACH YEAR

\begin{tabular}{lrc}
\hline Year & $\begin{array}{c}\text { Schools Which Are } \\
\text { Presently Teaching } \\
\text { the Course }\end{array}$ & $\begin{array}{c}\text { Schools Which Have } \\
\text { Discontinued } \\
\text { the Courge }\end{array}$ \\
\hline $1954-55$ & 1 & \\
$1953-54$ & 10 & 1 \\
$1952-53$ & 10 & 3 \\
$1951-52$ & 4 & 1 \\
$1950-51$ & 10 & 1 \\
$1949-50$ & 2 & 1 \\
$1948-49$ & 7 & \\
$1947-48$ & 4 & \\
$1946-47$ & 3 & \\
$1945-46$ & 2 & \\
$1944-45$ & 1 & \\
$1943-44$ & 2 & \\
$1942-43$ & 1 & \\
$1941-42$ & 1 & \\
$1940-41$ & 2 & \\
$1938-39$ & 1 & \\
1931 & 1 & \\
1924 & 1 & \\
Unknown & 16 & \\
Total & 79 & \\
& & \\
\hline
\end{tabular}


TABLE VII

TITLES USED FOR THE COURSES IN PHYSICAL SCIENCE AND THE NUMBER OF SCHOOLS USING EACH TITLE

Physical Sctence or

Physical Science Survey

Senior Sclence?

Practical Science

Advanced Science

General Science

Applied Science

Consumer Science

Vocational Science

Advanced General Science

Basic Science

Earth Science

Practical Physics

Sctence for Modern Living

Science XI

Shop Science

Trade Related Sciences

Did Not Indicate

48

8

6

5

3

2

2

2

1

1

1

1

1

1

1

1

3

Total

87 
physical sciences, one school indicated that approximately twenty per cent of the time was used to study consumer education; one school mentioned that about twenty-five per cent of the time was being used on current science; and one school listed aviation for approximately ten per cent of the study time. Another school taught what it considered to be a physical science course, titled Science $X I$, but indicated that one-fifth of the study time was used to explore the field of biology. Therefore, this could have been more of an sdvanced general science course, although it was included in the survey because four-fifths of the time was used to study the physical sciences. In one school a survey card asking for the particular interests of the students was filled out by each student the first week of the course, and the amount of time used in each subject area depended upon the results of these cards.

The percentages of time spent on each of the five physical science subject areas have been graphically presented in Figure 1. In order to find the average course content, the mean per cent of time spent to explore each of the subject areas was calculated to the nearest per cent. The following course of study was determined as the over-all average: astronomy, ten per cent; chemistry, twenty-three per cent; physics, thirty-ftve per cent; meteorology, sixteen per cent; and geology and physical geography, sixteen per cent. 
Percentage of Time: $\quad 0 \quad 5 \quad 1015202530354045505560$

Number of Schools:

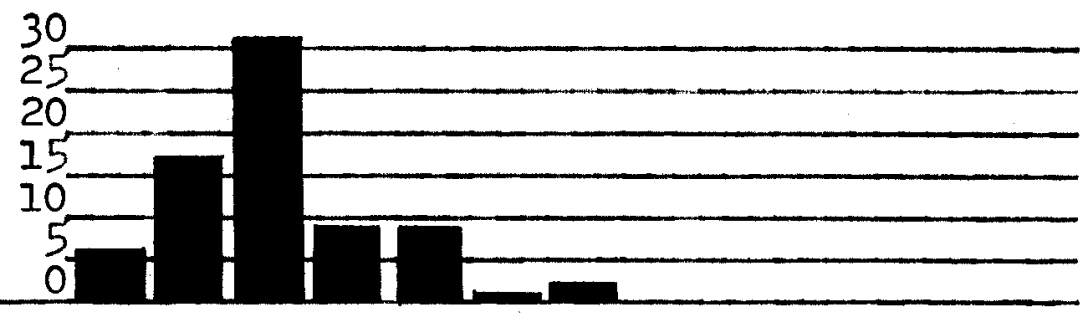

Number of Schools: 30

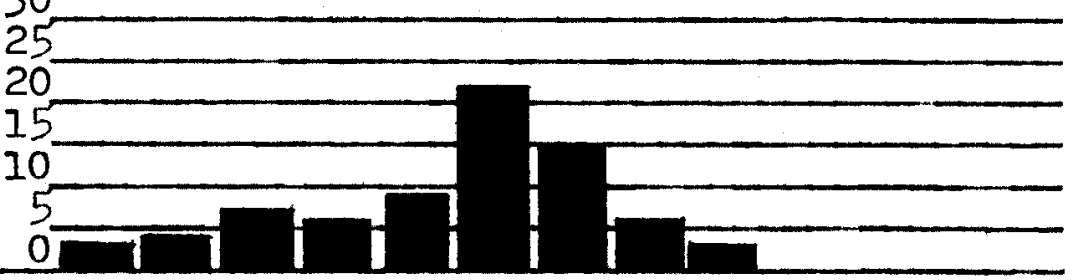

Number of Schools: 30

$$
25
$$

PHYSICS $\quad 15$

$$
20
$$

Average: $35 \%$
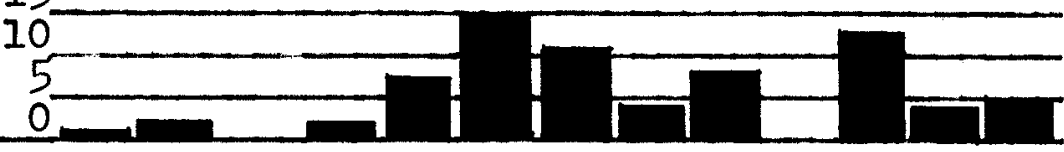

Number of Schools: 30

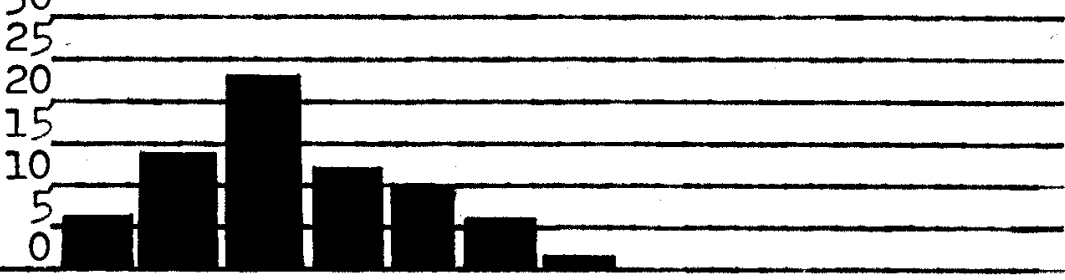

Average: $16 \%$

30

25

\section{GEOLOGY}

AND

PHYSICA $\overline{\mathrm{L}}$ GEOG RAPHY

Average: $16 \%$

\section{0}

15

10

5


The function and place of the course. The literature revealed that the three basic functions of the course in physical sctence were (1) a fusion of chemistry and physics and a substitute for those courses, (2) a step in the sequence of acience courses to provide a background for further high school study in one or more of the physical sctences, and (3) a terminal course for non-science majors or for those students not going on to college. In order to determine the predominant function and other pertinent data concerning the function, each school was asked the following series of questions: (a) Is this course required by your school? (b) Is this course designed as a terminal course for non-science majors? (c) Does this course substitute for chemistry or physics in your school's curriculum? (d) Was this course primarily developed to aid slow learners? and (e) Was this course destgned as a step in the sequence of courses to provide a background for further high school study in chemistry, physics, or other physical sclences? Table VIII shows the responses to the above questions. Due to the fact that three schools which had discontinued the course did not complete the que stionnaires in full, they were not included in the remainder of the study except for their comments. Therefore, the number of schools appearing in the tabulations has been reduced from eighty-seven to eighty-four. 
TABLE VIII

THE RESPONSES AND THE NUMBER OF SCHOOLS RESPONDING

TO EACH QUESTION CONCERNING THE FUNCTION

OF THE COURSE IN PHYSICAL SCIENCE

\begin{tabular}{cccc}
\hline & Did not \\
indicate & Yes & No & $\begin{array}{c}\text { Yes } \\
\text { and } \\
\text { No }\end{array}$ \\
\hline
\end{tabular}

(a) Required course $\quad 1 \quad 12 \quad 70 \quad 1$

$\begin{array}{lllll}\text { (b) Terminal course } & 1 & 68 & 13 & 2\end{array}$

(c) Substitute for chemistry or physics

1

23

60

0

(d) To aid slow learners

0

47

34

3

(e) Step in the sequence

0

18

65

1 
The survey revealed that the course functioned predominantly as a terminal course for non-sctence majors. A total of seventy schools reported that the course served this function. Of these, forty-two schools indicated that this was its only function. Fifteen schools combined this function with that of gerving as a substitute for chemistry or physics; seven schools indicated that the course served as a terminal course as well as a step in the sequence of courses; and six Bchools reported that the course served all three functions.

Twenty-three schools reported that the course functioned as a subatitute for chemistry or physics. However, only two schools taught the course exclusively as a substitute for these subjects and offered no separate courses in chemistry or physics. One was a vocational school which taught a two-year course combining physics and chemlstry. The other was a four-year high school which stressed chemistry and physics, but included the other physical sciences. . Both of these were included in the fufteen previously mentioned schools which combined the terminal and substitute functions for the course. All of the other schools which listed the substitute function--tncluding the one school which listed only this function, the one school which listed this and the step in the sequence function, and the six previously mentioned schools 
which listed all three functions--offered separate courses in chemistry and physics. In fact, only five schools in the entire survey did not teach both chemistry and physics. Two of these were the schools just mentioned which offered neither subject. The other three schools offered chemtstry but not physics. It was interesting to note at this point that none of these three schools indicated that the physical science course functioned as a substitute for physics.

A total of nineteen schools indicated that the course functioned as a step in the sequence of courses to provide a background for further high school study in one or more of the physical sciences. Five schools indicated that this was the only function of the courge. As previously mentioned, seven schools combined this with the terminal function, one combined it with the substitute function, and six schools listed all three functions.

It had been brought to light through discussions with teachers and college professors of science education that two other aspects which might affect the attitudes of teachers and atudents toward the course would be whether or not it was placed in the curriculum (1) as a required course, and (2) as a course primarily developed to ald slow learners. Only twelve schools reported that the course was required. Seven of these commented to the effect that it was required only if one of the other sciences--i.e., chemistry, 
physics, biology, etc.--was not taken to fulfill the science requirement for graduation. Two of the schools which replied that it was not a required course made aimilar comments that it could be taken in fulfillment of the school's science requirement. This seemed more logical in regard to the required aspect, but a more definite conclusion cannot be reached without further research. A total of fifty schools indicated that the course was primarily developed to ald slow learners, and two echools which gave a negative response commented that the course was "not primarily" developed for this purpose and that it "partly" served this purpose. Table IX was presented to relate the three functions with the required and slow learner aspects.

\section{SOME CURRENT PRACTICES USED IN TEACHING} THE COURSE IN PHYSICAL SCIENCE

The literature revealed very little significant information concerning the current practices being used by those who teach the high school course in physical science. The questionnaire for the present study included questions concerning some of the most significant materials and activttes used in teaching the course. 
THE THREE FUNCTIONS OF THE COURSE

RELATED TO THE REQUIRED AND SLOW LEARNER ASPECTS

\begin{tabular}{|c|c|c|c|c|c|}
\hline $\begin{array}{l}\text { The Function or } \\
\text { Functions Indicated }\end{array}$ & $\begin{array}{l}\text { Not required, } \\
\text { Not for slow } \\
\text { learners }\end{array}$ & $\begin{array}{c}\text { For } \\
\text { slow } \\
\text { learners } \\
\end{array}$ & Required & $\begin{array}{c}\text { Required } \\
\text { and for } \\
\text { slow learners }\end{array}$ & $\begin{array}{l}\text { Total } \\
\text { Schools } \\
\end{array}$ \\
\hline $\begin{array}{l}\text { Terminal course for } \\
\text { non-sclence majors }\end{array}$ & 14 & 22 & 2 & 4 & 42 \\
\hline $\begin{array}{l}\text { Substtute for chemistry } \\
\text { or physics }\end{array}$ & 1 & & & & 1 \\
\hline $\begin{array}{l}\text { Terminal course for non-scier } \\
\text { majors and substitute for } \\
\text { chemistry or physics }\end{array}$ & ce & 9 & 1 & 2 & 15 \\
\hline $\begin{array}{l}\text { Step in sequence of courses to } \\
\text { provide background for } \\
\text { further study }\end{array}$ & 3 & 2 & & & $\mathbf{5}$ \\
\hline $\begin{array}{l}\text { Terminal course and step in } \\
\text { sequence of courses }\end{array}$ & 3 & 3 & 1 & & 7 \\
\hline $\begin{array}{l}\text { Substitute for chemistry or phy } \\
\text { and step in sequence of cou }\end{array}$ & sics & 1 & & & 1 \\
\hline $\begin{array}{l}\text { Terminal course, substitute fo } \\
\text { chemistry or physics, and } \\
\text { step in sequence of courses }\end{array}$ & 3 & 1 & 1 & 1 & 6 \\
\hline None of these functions & 2 & 5 & & & 7 \\
\hline
\end{tabular}


Materials used in teachtng the course. The schoole surveyed were asked (1) for the title and author of the textbook used, (2) what other types of teaching matertaia were used, (3) what difficulties were encountered in obtaining texts and other materials, (4) If films and fllmstrips on the appropriate subjects were resally avallable, (5) what fllmo and flimstripe have been found most valuable, and (6) what difficultie have arisen in securing the proper flims and filmstrips.

Due to the fact that the bastc malling list for the survey wa received from the publishers D. Van Nostrand Co., Inc., it wa antictpated that nearly all of the achools in the ourvey would be using their text Physical Sclence For High Schools by Hogf. Crosa, and Little. Fifty-geven of the schools were using this text; twelve schools were using Modern Fhystcal Science by Brooks and Tracy: three chools were using The Physical Selences by Eby, et al.: and three schools were using New Senior Sctence by Busch and Thompson. Five other texts were named; these were shown in Table $X$ with the complete list of books mentioned, their various combinations, and the number of shools uaing them.

When asked whet other types of materials were used in teaching the course, the following were liated most frequently: films and fllmstrips; pamphlets, bookiets, brochurea, and science magazines; reference books and additional texts; charts. plctures, 
TABLE X

THE TEXTBOOKS AND COMBINATIONS OF TEXTBOOKS AND

THE NUMBER OF SCHOOLS USING EACH FOR TEACHING

THE COURSE IN PHXSICAL SCIENCE

Textbook or Combination of Textbooks

Schools

Physical Science For High Schools,

Hogg, Croas, and Little

Modern Physical Science, Brooks and Tracy

The Physical Sciences, Eby, et al.

New Senior Science, Busch and Thompson

Graphic Survey of Science, Lemkin

Everyday Science, Caldwell and Curtis 1

Our Physical Environment, Gaddum and Knowles 1

Science For Better Llving, Brandwein, et al.

Physical Science for High Schools and Physics and Chemistry Textbooks

Physical Science for High Schools and

Modern Physical Science

Physical Science, for High Schools,

Modern Physical Science, and

Applied Chemistry, Wison and Mullins 1

Physical Science For High Schools and

The Physical Sciences 
TABLE X (Continued)

Textbook or Combination of Textbooks

Number

Textbok or Combination of Textbook

of

Schools

Physical Sctence For High Schools

and physics, Chemistry, and

Geology Textbooks

No Text for course--Phygical Science for

High Schools used as supplement

Modern Phystcal Science end

New Senior Sclence

The Physical Sciences and

Physics, Earth Science, Pre-Flight, and other Textbooks

Set of Textbooks--Physics, Chemistry,

and otherg

Earth Sclence Textbook

Earth Science, Physics, and Chemistry Textbooks 2

Did not indicate 
globes, maps, and models; teaching aids from General Motors, General Electric, and other industrial concerns; and workbooks, laboratory manuals, and demonstration and laboratory equipment. A number of persons indicated the development of their own manuals or work sheets for work with spectal related toples such as electricity, redio, photography, and weather.

In regard to difficulties, forty-seven schools either left the question blank or indicated definitely that they had encountered no difficulties in securing adequate textbooks and other materials. Thirty-one schools reported difficulties in obtaining adequate texts; two schoois expressed difficultie $s$ in securing texts and other materials; three reported inadequate funds for securing proper laboratory equipment or insufficient quantity of materials and references; and one school's comments were not pertinent to this subject.

Of the forty-seven schools which indicated no difficulties in securing texts and other materials, nine tncluded comments which were as follows: "I have taught the class only one year and have not had much trouble;" "None so far. The text is a fairly recent edition"; "Book must be selected with care. Material should be well balanced in different fields"; "Text was adopted after careful comparicon with other like texts and how it fit in 
with our philosophy of science": "We have very good library and laboratory resources and a generous science department budget"; "I believe we have an adequate supply of teaching materials"; "We use several reference books in addition to the one above": "The use of the library and periodicals is encouraged. Also supplementary material is given by the teacher on new units not included in the book"; and "A number of new books are available for this course."

Of the thirty-one schools which expressed difficulties in securing texts, four complained of general regulations for gecuring texts and not of specific difficulties concerning texts for the physical science course, and nine schools commented that there was a lack of good textbooks on the market from which to choose. Three schools indicated that the texts were not difficult enough for their students. One person commented that the texts were "Not difficult enough for seniors. We used the most advanced elementary text we could find." Another stated that it was felt that the texts "... are not of sufficient difficulty for the se [eleventh and twelfth] grades."

Three schools indicated that the texts available were too difficult for their students. This was expressed by the teachers as follows: "Our text is really beyond the reading level of many of our pupils": "Most texts are for eleven [and] twelve [grade] normal 
or above students. We are teaching a below average student"; and "No book is... simple enough to meet interesta and ability level."

Six schools felt that the texts were not suited to the purposes of the course as they taught it. The feelings were expressed by four of the teachers as follows: "Seems impossible to locate a textbook covering only phystcal science adapted for ninth graders"; "No adequate book on the college preparatory level is available"; "... Text not set up to serve purpose of course"; and "No textbook adequate for the course we teach has been found." Another tencher stated that

No book so far fits a local situation. However, the text we use if a handy reference and perhaps the only source that some will use. There probably will never be $a$ one and only cr best book.

Another teacher expressed the problem in her school as follows:

We have been unable to find a text aptly guited to the rather vague purposes of this course. Essentially, the problem evolves from the advanced knowledge along many varied and practical lines. Several of the boys are already ftne mechanics and some have developed technical skills. The major interest is along practical lines, while texts seem to delve into theorles which are over the heads of the greater number of gtudents who take this course. The practical-theoretical balance is not applicable to the group.

The difficulties expressed by the six remaining schools were hard to classify with any group. One teacher indicated that he ".. would IIke a aimple version of Gerald Holton's Introduction 
To Concepts and Theories In Physical Science." Two other teachers expressed the feelings that most texts "... tend to be unbalanced in one of the special science fields" and "... are just watered down chemistry and physics." The remaining comments on this subject were as follows: "One of our texts is a poor duplication of the ninth grade text. We use Modern Physical Science ... one semester. Too much duplication here to keep interest of Btudenta"; "Many toplcs too briefly treated"; and "For our mixed class (a few very bright, others low) we find all books go too fast, do not give enough to make each point comprehensive. Have to do much supplementing."

A significant point which was partially shown in (1) the list of materials used, (2) Table $X$, and (3) three of the preceding comments was the extensive use of supplementary texts and other literature by those who were teaching the course. Forty-one schools, or nearly half of the schools surveyed, indicated the use of supplementary material in one form or another. Table XI was included to show the number of schools using (1) multiple texts (as were shown in Table X), (2) supplementary texts or reference books and library references, (3) pamphlets, booklets, brochures, and science magazines, and (4) combinations of two or more of these.

When asked if films and filmstrips were readily avallable, seventy-one schools answered in the affirmative and ten schools 
TABLE XI

THE NUMBER OF SCHOOLS USING MULTIPLE TEXTBOOKS AND SUPPLEMENTARY READING MATERIALS, AND COMBINATIONS OF THESE

The Materials Indiceted Number of Schools

Multiple Textbooks 3

Multiple Textbooks and Supplementary Texts and References

Multiple Textbooks and Pamphlets

Multiple Textbooks, Supplementary Texts and References, and Pamphlets

Supplementary Texts and References

Supplementary Texts and References and Pamphlets 
answered in the negative. Three schools were indecisive on this matter with two answering "yes and no" and one answering that "some" were readily available. A list of titles, types, and sources of flims and filmstrips found to be most valuable for teaching the course were presented in Table XII.

Very few schools expressed any difficulties encountered in securing appropriate films and filmstrips. Only two schools indicated a lack of published film materlal; eleven indicated difficulties in scheduling fllms at the degired times; and two schools were concerned with the expense involved in obtaining fllms and filmstrips. One teacher commented on the subject by stating that the films for the course were "Much the same as ninth grade general science in .. . New York state, " and another teacher who taught a course designed to ald slow learners atated that "Not too many of the films portray that which these students can grasp." Two other comments received in regard to this aspect were as

\section{follows:}

I am somewhat indifferent to films and strips unless basic information is first imparted. Films move so fast it's Impractical to stop for questions or find out if tndifferent students are following the films. Breaking in on film run destroys continuity--loss of interest results.

I consider fllmstrips a better teaching aid than the regular projector because emphasis can be placed where most needed. If entire film must be run before discussion, often students have missed important points. 
TABLE XII

TITLES, TYPES AND SOURCE OF FILMS AND FILM STRIPS

FOUND MOST VALUABLE IN TEACHING THE COURSE

Types

Number of Schools

Those pertaining to chemistry

Those pertaining to physics

Those pertaining to geology

Those about water

Those pertaining to conservation 2

Those aimllar to the Jam Handy series 2

Those pertaining to meteorology 2

Those about aluminum 1

Those pertaining to astronomy 1

Those about aviation 1

Those illustrating chemical reaction 1

Those about electricity 1

Those about heat and temperature 1

Those pertatning to industry 1

Those about lubrication 1

Those about nucleonics 1

Those which show actual process 1 
TABLE XII (Continued)

Types

Number of Schools

Those illustrating physical science principles

Those illustrating topics hardest to visualize 1

Those pertaining to various trades 1

Atomic Energy 4

The World We Live In Series 6

The A B C ' $\mathrm{B}$ of Internal Combustion Engines

Volcanoes in Action 3

Steelman'g Servant 3

A Is for Adam 2

Sound Waves 2

A B C 's of Hand Tools 1

Air Age Physics 1

Chemistry of Fire 1

Electrons 1

Electro-chemistry 1

Electrostatics

Forces in motion 1

Fuel and Heat 1

Fundamentals of Acoustics 1 
TABLE XII (Continued)

Titles

Number of Schools

The Halogens

1

Home electrical appliences

1

The Nature of Light

1

Nuclear Structure

Oil from Earth to You

1

Oil Prospecting

1

Simple Circuits

1

Simple Machines

1

Sound and Light

1

Story of a Storm

1

Story of Oil

1

Weather

1

Winds and Weather

1

Sources

Number of Schools

General Electric

General Motors

Shell Oll Company

Bureau of Mines 
TABLE XII (Continued)

Sources

Number of Schools

Life Magazine

4

Various State Department

3

Du Pont

2

Ford

2

Westinghouse

2

Bell Telephone

Freeport Sul fur Company

1

Naval Reserve Library

1

New York Times

1

Personally Prepered Films and Slides 1

Popular Science Series 1

Science Monthly Series 1

Welsh Company 1 
Activitles used in teaching the course. In addition to

surveying the use of textbooks, films, and other materials, this study sought to disclose some of the activities pursued in teaching the course in physical science. The schools were asked (1) for the type of laboratory work done in the course, (2) what the teacher felt would be the best type of laboratory work for the surse, (3) how many field trip were taken in conjunction with the course, (4) which field trips were felt to be the most valuable. (5) how many resource persons were invited to the class during the course, (6) which resource persons the teacher felt were most valuable, (1) what was done in teaching the course to encourage science hobbies, (8) if student science projects were required, (9) what was done to stimulate student interest in science projects, and (10) what opportunities were avallable to the students for displaying and receiving recognition for their projects.

The persone completing the questionnaires checked one or more of the following types of laboratory work being used: (1) frequent or regularly scheduled laboratory periods, (2) occasional laboratory periods as needed or at the teacher's discretion, (3) student demonstrations, and (4) teacher demonstrations. Sixtysix of the eight-four schools were using more than one type of laboratory work. The complete tabulation with the number of schools using each type or cornbination of types was shown in Table XIII. 
TABLE XIII

THE TYPES OF LABORATORY WORK, THEIR COMBINATIONS, AND THE NUMBER OF SCHOOLS USING EACH IN TEACHING THE COURSE IN PHYSICAL SCIENCE

Type of Laboratory Work Belng Used Number of Schools

Frequent or regularly scheduled laboratory periods

Occasional laboratory periods as needed or at the teacher's discretion

Teacher demonstrations

Frequent or regularly scheduled laboratory periods and teacher demonstrations

Frequent or regularly scheduled laboratory periods, student demonstrations, and teacher demonstrations

Occasional laboratory periods or at the teacher's discretion, and Teacher demonstrations

Occasional laboratory periods or at the teacher's discretion, student demonstrations, and teacher demonstrations

Student demonstrations and teacher demonstrations 
In terms of total numbers, fifteen schools indicated the use of frequent or regularly scheduled laboratory periods; thirty-nine schools indicated occasional laboratory periods as needed or at the teacher's discretion; forty-nine schools indicated student demonstrations; and elghty schools indicated the use of teacher demonstrations.

The teachers' opinions varied greatly as to what type of laboratory work would be best suited for the course. Twenty-five teachers felt that student demonstrations and/or well-supervised individual experiments would be most valuable to the students. Four additional teachers expressed the opinion that students would remain interested--and consequently gain more--by performing short, simple experiments which they could eastly grasp. However, four teachers noted that such work could not easily be handled in classes with large enrollments; and two teachers, although they felt that individual student work would be preferable, indicated that their limited laboratory facilities would not permit it.

Two teachers felt that occasional laboratory periods as needed would be best suited; six felt that the course called for frequent or regularly scheduled laboratory periods; nine indicated that teacher demonstrations were most applicable; twelve teachers felt that the combination of teacher and student demonstrations would 
be most valuable; and one teacher expressed the opinion that no laboratory work of any kind should be used. One teacher who felt that only teacher and gtudent demonstrations should be used for the course explained that the physical science class met orly five periods a week and not seven periods as his laboratory classes did. Another teacher whose course was designed to aid slow learners stated that "Because of the caliber of student that takes thls course, we feel that demonstration techniques are most rewarding." Another teacher felt that the laboratory work for the course should be "Experlences in some phase of the work in which doing or experiencing will lend more meaning to and understanding of the concepts involved."

Forty schools indicated that no field trips were taken in conjunction with the course, and three achools did not complete this portion of the survey. The responses received from the remaining forty-one schools varied from "zero to one" to "eight to ten" field trips. Table XIV shows the complete list of responses concerning the number of field trips taken.

A list of field trips considered most valuable was compiled from the teachers' responses and was presented in Table XV. The list was classified in terms of trips to (1) public utilities, (2) manufacturing plants and industrial concerns, (3) science exhibits and 
TABLE XIV

THE RESPONSES CONCERNING THE NUMBER OF FIELD TRIPS

TAKEN IN CONJUNCTION WITH THE

COURSE IN PHYSICAL SCIENCE

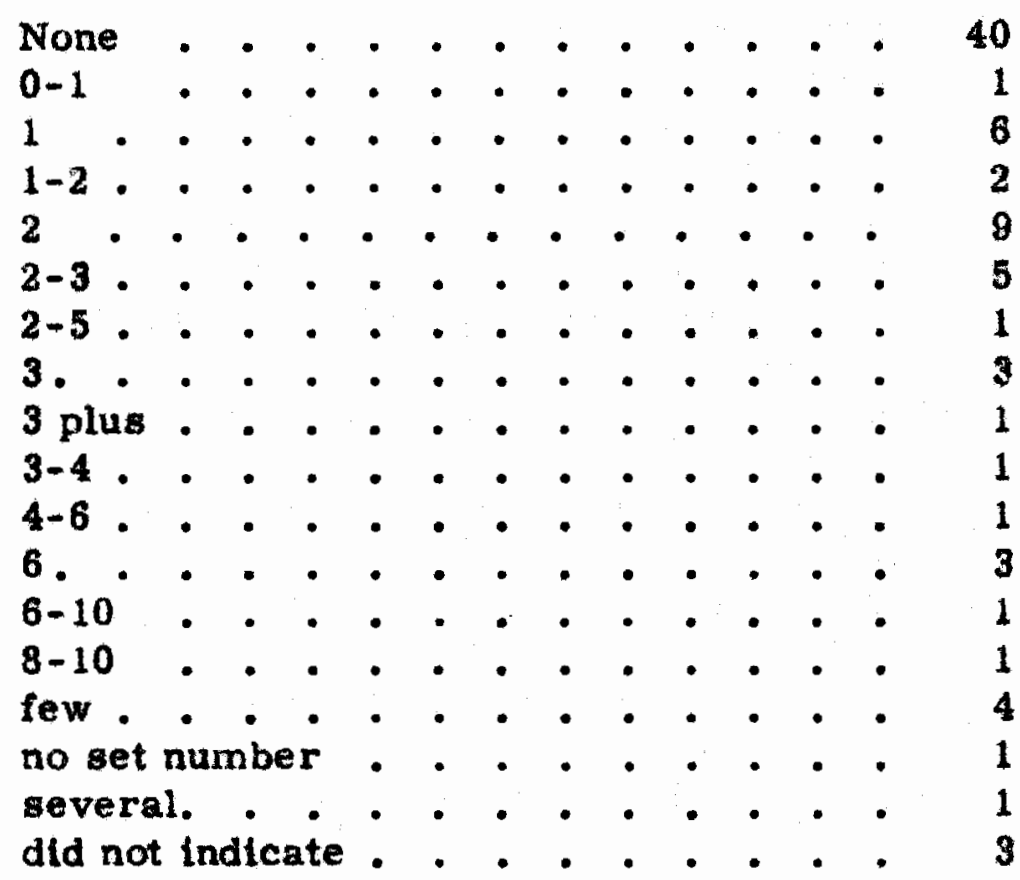


TABLE XV

FIELD TRIPS CONSIDERED MOST VALUABLE BY THE PERSONS TEACHING THE COURSE IN PHYSICAL SCIENCE

Type of Field Trip

Number of Schools

To Public Utiltties:

Water

Sewer

3

Power

3

To Manufacturing Plants and Industrial Concerns:

Undefined Local Industry

Glass Works

Paper Mill

Fertilizer Plant

Foundry

Steel Mill

Heavy Industry

Rallroad Shops

Chemical Plants

1

1

Aviation Motor Repair

1

Carbon Plant

Tire Factory

Beryllium Plant

To Sctence Exhibits and Scientific Operations:

Museums

Science Museums

Astronomical Observatory

Weather Station

Planetarium

Research Laboratory

To Observe Geological Formations:

Undefined Geology Trips

Wasatch Fault by Salt Lake City 
scientific operations, and to observe (4) geological formations.

Five teachers noted that field trips were difficult to arrange due to school policy limitations, limitations of the area, or because of the large enrollments in the physical science classes; two teachers expressed the feelings that the students were not sufficiently interested in field trips; and one teacher indicated that all field trips were sponsored by the science club and that only members were allowed to participate.

Fifty-three schools indicated that no resource persons were invited to the class. Of the thirty-one remalning schools, one indicated that resource persons were invited "as needed"; one indicated "occasionally"; two replied "few"; ore replied "some"; one replied "several"; one school Indicated that the number of persons invited "varies"; and six schools did not cornplete this portion of the questionnaire. The efghteen replies which were in terms of definite or approximate numbers varied from "one to two" to "eight to ten." These flgures were shown with the number of schools which indicated them in Table XVI. Four teachers commented that although no resource persons were invited to the physical sctence classes, a number of persons from the scientific fields spoke frequently in the all-school assemblies.

A list of resource persons constdered mast valuable was 
TABLE XVI

THE RESPONSES CONCERNING THE NUMBER OF RESOURCE PERSONS INVITED TO CLASS FOR THE

COURSE IN PHYSICAL SCIENCE

The Number of Resource

Number of Schools

Persons Invited

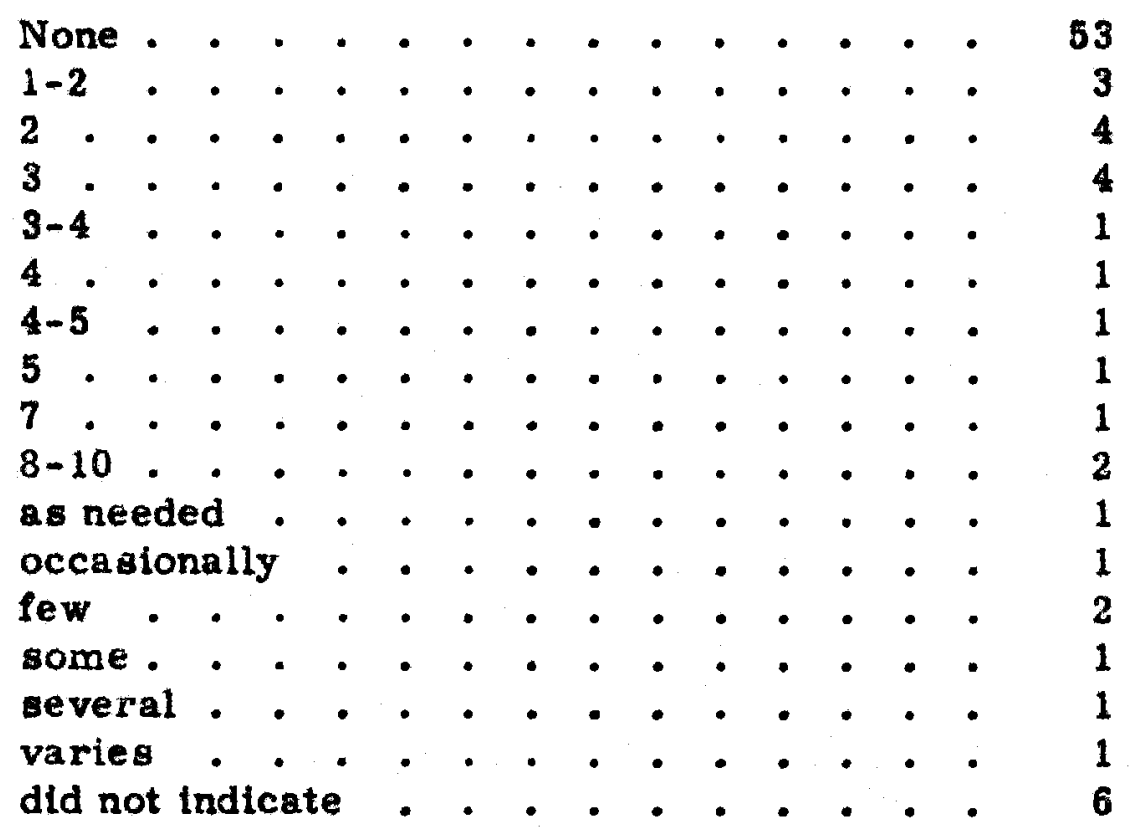


presented in Table XVII. The ligt was classified in terms of persons from (1) public services, (2) industry, and (3) scientffic flelds. Six teachers replied that resource persons from all fieldo related to physical science were equally valuable; one teacher specified that the visitors should be "People engaged in activities requiring scientific background"; and another specified that the persons should be "Those who work in the fleld to which the unit [being studied] is closely related" to be of the most value to the students. Another teacher indicated that it was difficult to determine which resource persons ware most valuable: "It varies with the class and resource person. A short talk and demonstration followed by questions holds greatest interest."

A vartety of methode were used by the teachers to encourage interest in science hobbies. Fourteen teachers promoted this aspect either through constant encouragement or emphasis, by continuously making appropriate suggeations, or by attempting to show the value of science and science hobbles in relation to the students' vocational ambitions. Twelve teachers approached this aspect through reading and class discussions, demonstrations, and reports. Seven teachers encouraged science projects and five other teachers required projects as a method of promoting the hobby aspect; nine teachers indicated that activities such as photography, stone and gem cutting and 
TABLE XVII

THE RESOURCE PERSONS CONSIDERED MOST VALUABLE

BY THE PERSONS TEACHING THE COURSE

IN PHYSICAL SCIENCE

From Public Services:

Representative of Power Light Co. 1

Power Plant Engineer

Undefined Local Utilitieg

Hospital Superintendent

Conservation Agent

Vocational Agriculture Instructor 1

College Instructors

Weather Man 1

Speaker on Fire \& Fire Control 1

From Industry:

Undefined Industry 2

Metallurgisi 1

Chemist 1

Manufacturing Foreman 1

Representative from Steel Plant 1

From Scientific Fields:

Speaker on Earth Sclence 1

Speaker on Geology 1

Speaker on Space 1

Speaker on Aviation 1

Astronomer 1 
polishtng, or rock collecting stimulated student interest in science hobbies: four teachers indicated that student interest was stimulated through sclence clubs; five teachers encouraged the students to enter hobbles in science fatrs, U. S, science talent contests, or the Jr. Acaderny of Science; and three teachers encouraged hobbles through required written work and through the use of room displays. Ten teachers replied that very little was done directly, and twelve replied that nothing was done to atimulate the students' interest in science hobbles.

When akked if student sclence projecte were required, fifty-six teachers replied that they were not; twenty teachers replied that they were; two indicated that they ware "Bometires" required; one teacher stated that both methods had been tried; and five teachers indicated no answer to this question. One teacher who indicated that projects were not required commented that "It would be a good requirement for $A$ and $B$ aspirants."

Some of the methods used by the teachers to stimulate student interest in science projects were much the same as those indicated in regard to the hobby aspect. Nineteen teachers promoted interest through encouragement, suggegtions, and help whenever needed; fifteen teachers encouraged the students to display their projects in school exhibitions or in local or regtonal science fairs; five indicated 
that interest was stimulated through the science clubs; three teachers aroused the students' interest through demonatrations and the showing of fllms; and three teachers commented that the students received special recognition and commendation from the teacher and student for work on projects. Six teachers indicated that student projects ware on an entirely voluntary basis; three indicated that little was done in this area; and seven teachers indlcated that nothing was done in regard to science projects.

In regard to opportunities available to the students for displaying and recelving recognition for their projects, fifty-six schools indicated the avallability of either local or state science fairs, shows, displays, or conteats for science scholarships. Nine schools indicated that opportunities were limited to classroom and school demonstrations and displays, and nineteen schools indicated that there were no opportunities avallable.

Some additional practices used in teeching the course. The schools surveyed were asked what was done in conjunction with the course to accomplish the following: (a) the teaching of the scientific method and its application to every-day living, (b) the building of a scientific vocabulary, (c) the development of open-mindedness, scientific curlosity, healthy skeptictsm, and sustained thinking, and (d) the development of an apprectation of science. 
The fcientific method and it application to every-day living was introduced to the students through (1) activities, (2) reading and discussions, or (3) stressing its use throughout the course. Fourteen teachers felt that activitien such as projects, laboratory experiments and demongtrations, and working out specific everyday problems which involved the use of the scientific method would be of the most value in approaching this area. One teacher who Indfated the use of laboratory work added the comment that "ElimInation of guess work must be stressed, "and another teacher noted that all activities in hif clase were "keyed to the idea of thinking through critically all problems."

Nine teachers indicated the uge of class discussions and reports on material the etudents had read from the textbook, periodicals, and newspapers. Twenty-geven teachers replied that they stressed the seleatific methot and its application to every-day living throughout the duration of the course. Six teachers combined the use of reference materials and discussions with activities to approach this aspect; five teachers Indicated that little or nothing was done in this area; and twenty-three teachers gave no direct indication or no answer to this question. A few of the latter group of teachers referred to this question in the section of the questionnaire devoted to comments and the se will be discussed at ater point. 
In regard to the teaching of a scientific vocabulary, thirtytwo teachers did not indicate what was done in their classes to acquaint the students with the correct definitions and usage of scientific terms. Ftve teachers indicated that it was important to keep scientific terms at a minimum due to the caliber of students In their classes. In general, the remaining forty-seven teachers who participated in the survey placed a great deal of Importance on the teaching of a scientific vocabulary.

Seventeen teachers emphasize this aspect by constantly calling attention to and defining all new terms which arose in the daily work either from the textbooks or other sources, stressing the importance of their application, and encouraging the students to alway use correct terms in their oral and written work. Twelve teachers encouraged the students to observe the correct usage of sctentlfic terminology in the textbooks, other reference books. periodicals, and newspapers. Fifteen teachers had organized vocabulary training programs which included regular or frequent drills, quizzes, or tests, and which often included practices from one or both of the above categories. Three teachers indicated that work was done in this area but did not indicate any of the practices used. One of these teachers replied that the teaching of a scientific vocabulary" ... Is the chief object along with the presentation of 
the very basic concepts of sclence ..." and another commented that "New concepts and new meanings naturally lead to a broader vocabulary."

Forty-eight teachers replied to the question which asked what was being done to develop open-mindedness, sclentiftc curlosity, healthy skepticism, and sustained critical thinking. Eight teachers replied that little could be done in regard to this aspect due to the grade level of the students or to the fact that their classes were composed primarily of slow learners who could not grasp these concepts. Ten teachers indicated that they took advantage of every opportunity to approach these Ideas, but did not indicate any practices used.

Seventeen teachers felt that class discussions, reports, or debates were the most applicable practices to introduce these thoughts to the students. Seven teachers indicated that they encouraged their students to do outaide reading from books, magazines, periodicals, and newspaper articles on scientific material, current science events, and new discoveries; all questions or Ideas which arose from this reading were then discussed in class. Two teachers (one of them from the above group) indicated that they used the laboratory method; one teacher indicated the use of projects; and four teachers indicated that they presented problems to the 
classes which would challenge the students' thinking abllities.

Fifty teachers responded to the question which asked what was belng done to develop an appreciation of science. Twelve teachers felt that the students developed an appreciation of science through their participation in (1) discussions, (2) reports, (3) projects, (4) student demonstrations and experiments, (5) bulletin board displays, (6) weather map study, and (7) field trips, and through (8) reading, (9) the viewing of flims, (10) having resource persons visit the school or the individual classes, and (11) the students' own individual experiences.

Eight teachers Indicated that in order to develop an appreciation of sclence in their students they stressed the idea that, as one teacher expressed it," .. science is the fundamental basis for all progress." They did so through (1) the use of audio-visual materials, (2) student reports, (3) field trips, (4) giving concrete examples, and (5) always expressing admiration for the wonders of sclence. As one teacher commented. "Appreclation is contaglous--if radiated it will be absorbed." Two teachers replled that they approached this area through the historical study of science; and six teachers stressed the historical aspect along with current developments in science and the everyday applications. They did so through (1) discussions, (2) reports, 
and (3) the use of films. Six teachers used the study of current science events and developments and stressed the application of sctence to everyday living. They felt that (1) encouraging reading. (2) holding discussions on current events and students' own problems, (3) student reports, and (4) offering examples of practical applications were the best practices to develop an appreciation of sclence. One teacher commented that he attempted to show his students" .. . the advantages of our scientific age over nonsctentific." He further stated "Youth of today want to be modern." Another teacher pointed out that, although every effort was made, "In one year it is very difficult to replace awe by understanding." Nine teachers indicated that they rttempted to instill an appreciation of sclence in the minds of their students, but did not offer any further information; three teachers replied that little was done in this vein; and two teachers' comments were unrelated to the subject. Two teachers' replies were not classified into any of the above groups. One commented as follows: "All topics are treated in a practical, everyday living manner and science is woven into fundamental concepts." The other replied that an intelligent appreciation resulted from "stressing the importance of science in all Its aspects with an aim toward understanding rather than bewilderment. . . ." 
Four persons gave no indications of what was done in conjunction with the course to approach the four preceding aspects, but did refer to these questions in the section of the questionnalre which was devoted to additional information and comments which the person completing the form felt were pertinent to the survey. One teacher wrote that, although a "serious attempt" was made, his students"... have been all non-college preparatory and the level of their ability and understanding fallo even below the ninth grade level at which our text is aimed. They come to the course with no science background, ... and the most that can be accomplished is to make them observe more carefully those things which are famillar to them." Another of these four teachers referred to the below average I. Q. and low reading ablity of his students and added that the se questions could be answered in terms of "... the personality of the teacher, who must be interested in the problem. The success or fallure of the course depends on his personality." This latter feeling was also expressed by another of these teachers who indicated that how well these goals were accomplished depended upon the abilities, personality, and interest of the person teaching the course. Another response which concerned these questiong was as follows:

This is not a college preparatory course and we do not teach for such specific alms. . . I I don't think that you 
can teach some of the things mentioned and I have gotten into some 'hot' discussions on this matter at Columbia University. . . L Let's put it this way--We teach the physical sciences against the background of our Western Culture and the tale of man's many successes and foolish mistakes. We seek to make them think-- We hope we succeed.

One teacher who answered briefly to these questions included a comment which stated: "All [of the] above goals are part of regular science teaching. It is difficult to isolate details. We attempt to develop a broad outlook and general scientific background."

III. THE VALUES AND LIMITATIONS OF THE COURSE IN PHYSICAL SCIENCE

The data which pertained to the values and limitations of the course in physical science were obtained from (1) a question regarding the college acceptance of the course, (2) a section where the schools which had discontinued the course were asked for some of the most important reasons for discontinuing $\mathrm{it}$, and (3) the comments from the questionnaires.

The college acceptance of the course. An important a apect concerning the values and limitations of the course in physical science has been the willingness of institutions of higher learning to accept the course for college entrance. The schools were asked 
to indicate how many of the colleges in their area accepted the course as part of the science requirement for entrance of (1) nonscience majors and (2) sclence majors in terms of (a) all, (b) many, (c) some, and (d) none. The responses which concerned how many colleges accepted the course for entrance of non-science majors were as follows: (1) twenty-one teachers replied all, (2) eighteen replied many, (3) fifteen replied some, (4) twelve teachera replied none, and eighteen persons did not indicate. The responses regarding how many colleges accepted the course for entrance of science majors were:

(1) seven teachers indicated all, (2) seven indicated many, (3) twentytwo indicated some, (4) twenty-four teachers indicated none, (5) one teacher replied "few," and twenty-three teachers did not indicate. Two of the teachers who did not respond to this question made notations that the course was planned as a terminal course and therefore they had not given the problem of college acceptance much thought. Another teacher who replied "none" in regard to both science and non-science majors stated that "so far the 'graduates" of this course have not been college material." Two other teachers indicated that, to the beat of their knowledge, the course was accepted frequently as an elective and occasionally as fulfilment of the science requirement, but that physics was definitely required for engineering students. 
Feasons for the schools having discontinued the course.

Eight schools which participated in the survey were not presently teaching the course in physical science but had taught the course in the past. Insight into some of the values and limitations of the course was obtained through an examination of the reasons given by these schools for discontinuing the course. In two of the schools, the value of the course had been to serve a specific need which no longer existed at the time of the survey. In one of these schools the course had functioned as a substitute for chemistry and physics and had been discontinued when a new science bullding with increased facilities permitted the school to offer individual courses in general chemtatry and general physics. The other school had taught the course to a specific group of boys with no math skills who needed a science credit. This school was extremely small and otherwise had no need of a course of this nature.

Some limitations of the course were brought out in the rematning six reasons given for discontinuing it. One person wrote that the students desired to take college board examinations and that there were no examinations in physical science, and another wrote that "demands of college entrance [had] caused its being dropped" in his school. This teacher also indicated that there was "no demand" for the course. Another teacher gave "lack of time and no particular 
need at this time" as the reasons for discontinuing the course. The three other reasons given were (1) that the course "was considered too general and limited to be effective"; (2) that the only students who took it "were those who needed points to graduate"; and (3) that there was "no adequately prepared teacher for such a course."

\section{Comments written in regard to the course. Further}

insight into some of the values and limitations of the course was obtained through examination of comments which the persons completing the questionnaires felt were pertinent to the survey. Fifty persons included comments on this portion of the questionnatre and of these, five were discussed with practices used in teaching the course. Fourteen of the remaining forty-five comments pertained to values, and nineteen pertained to limitations of the course.

Three teachers felt that the course was of cunsiderable value for students not going on to college. This was expressed by one of the teachers as follows: "The physical science class serves our school very well as a terminal course for the non-academic pupil." Another teacher added that they did a great deal in terms of consumer education in the course. The third teacher replied,

I have been teaching this course for fourteen years and feel it is very beneficial espectally for the boy or girl not going on to college. ... 
Since modern homes use so many electrical gadgets and chemistry is so prominent in everyday life, all individuals need basic training-- These with careful teaching can be gained in this course.

This same teacher further replied that she has "had students entering college pass creditably entrance tests given in chemistry and physics." The college examination aspect in terms of a value was indicated by another teacher as follows: "This is a splendid course. In a factual way many points come in college entrance examinations."

Four comments referred to the idea that the course was valuable as an aid to the slow learning students. As one teacher stated, "Physical science in high school is used to take care of science needs for the slow student who cannot do the work in physics and chemistry." This tdea was expressed further by another teacher as follows:

In our school this is primarily a non-college preparatory course and as such it draws people of low academic level-hence, we operate with a great deal of hlexibility--based on interests and abilities of each group.

The third teacher indicated that he was able to encourage the slow student to "do that which he is capable of doing." He further stated, "If he can accomplish something he becomes proud of himself and sometimes is invited to continue in sctence." The fourth teacher indicated that the course was valuable as a terminal course as well as 
to aid the students with little or no abllity lor chemistry or physics. This teacher commented further in terms of being able to give confidence to those students with limited abllities, and often being able to transfer them to chemistry or physics classes.

The following comment revealed another value of the course:

I feel that a course of this type can give the puplla a more broad over-all viewpoint of the entire science field that such spectfic courses as physics and chemistry to not.

A similar comment was that the course was designed "mainly to cover theories and principles of the sciences as applied in life and work" and that a great deal had been accomplished in this course "in so far as imparting an underatanding and apprectation for the sciences." The latter opinion was expressed by another teacher as follows: "We feel in the main the students do appreclate the changes of the past years and understand better their place in soclety as a result of this class."

The following comment was offered by a teacher from one of the schools which had discontinued the course:

Although we do not have such a course in our curriculum, I as a guidance counselor and acience teacher, believe that there is a need for it in the large high school as well as the small.

She went on further to say that she had taught such a course in the early $40^{\prime} \mathrm{s}$ in another school. The course had been designed for those students "who could not take chemistry and (or) physics" 
and to provide "additional training for those who would not go to college."

Two comments were written in terms of abjectives for teaching the course in physical science. One of these teachers was from a school which had discontinued the course. He otated that the course must "be a medium through which to condition the student in those ways and attitudes which democracy has found to be most helpful in preserving Itself and equipping the student for a useful and purposeful life." The other teacher replied that, in his school, the course had as some of its objectives:

(1) to prepare those students who wish to take technicians training in school, (2) to build an appreciation for the efforts man has made in his progress through science, (3) to understand the basic principles upon which sctences are based, (4) to apply principles of chemistry and physics to practical situations.

In terms of limitations of the course in physical science, one teacher commented that, "We have learned enough over the past three years that we know the course needs rethinking and reorganization"; another replied that, "Our course is in a developmental stage and it will change from year to year as we study its results"; and a third teacher commented that "the physical science course has an important place in the high school curriculum, but at the present time ... Its position to not clearly defined." Another teacher stated that, 
This could easlly have been the most effective class in school but it was not used to the best advantage of the students. The students were largely over-age and slow learners. This course began last year as a senior science course and was changed this year to practical physics. .. . If it becomes a straight physics course, the purpose of the course will be defeated.

Another limitation was brought out by a teacher who felt that "the course in physical acience in many instances is still looked upon 28 a device for placing puplls in the curriculum when they won't fit anywhere else. In other words, a dumping ground." This difficulty was expressed by five additional teachers, most of whom added that the course also attracted students who were seeking an easy credit and who would not become interested in the course. One teacher's comments were quite emphatic on this issue. He stated that the course was a "dumping ground for the slow learner, discipline problem, and for the boys taking the shop course"; that "it's a catch-all for those students who must stay in school because of age and are not interested in learning"; and that it "also satisfies the science requirement to graduate." This teacher also reported that at a recent meeting of science teachers in northern Illinois and southern Wisconsin, "most of the schools teaching physical science reported the same thing." He concluded his comments by stating:

Lack of good texts and interested teachers I believe is the reason why physical sclence is having trouble. As I see it, it's an oversize general science course and a boiled down physics. 
Another teacher reported that the title of and the material to be covered in the physical science course had been changed nearly every year, and he further stated:

The course in our school has for all practical purposes been one in which five easy credits can be had--not educationally sound, but with the limit of books, sound aims and organization, it flounders around each year, depending upon the interests of the person who happens to be teaching it.

One teacher felt that the course in physical science "must be taught by physics and chemistry teachers who realst 'reconatruction.' This is the largest problem facing the course." Another teacher stated that, "Better attftudes are needed by those who teach the course." Two other teachers commented on this aspect, one of whom indicated that training in geology, meteorology, and astronomy was necessary as well as in chemistry and physics.

Four teachers' comments revealed that the course was goIng to be discontinued in their schools after completion of the current school year. The reasons given for this action disclosed some additional limitations and some which had been previously mentioned. One teacher stated that the course was being discontinued "because there is too much duplication of general science and biology." Another indicated that the courae was "too difficult for about half the class and hardly good enough for the rest" and that it 
was belng replaced by courses in earth science and practical physics, Another teacher commented that he felt the text was "good and the course interesting if the caltber of the students is high enough," but that the course "became a dumping ground for nunk-outs and people who just needed that one more credit." This course was being replaced by a "more practical course for shop boys." The fourth teacher indicated that, "Physical science will be dropped at [the] end of the school year to allow for science in seventh and eighth grades, due to $[\mathrm{a}]$ reduction in the science staff."

The remaining comments were difficult to clasify in terms of specific values and limitations, but it was felt that many of them were interesting and were pertinent to the survey. Two of them were explained in the sections of the text to which they pertained. The remaining comments were listed a follows:

Trend I believe in north California is toward getting as many students on the elghth and ninth grade levels to commit themselves in required general sclence classes to mathematical sciences as far as possible. In larger schools one or two sections should be for non-math students.

This is a non laboratory course designed for those who elect biology as the science graduation requirement. It is meant to give a survey of the physical sciences.

The teaching of fundamental principles is sought above all else. It is intended that these be supported by adequate factual information, but the intention is to stress idess and to give practice in their application in new situations. 
There is a constant danger that a course of this kind will have too much breadth and too little depth.

Since physical science is a substitute courae for physics for those non-college students or students that are not qualified to take physics, the teacher should put more emphais on the practical aspects rather than theory.

We have one course organized on a two-semester basis so that it covers the same phystcs units each half year that are being covered in physics. But it is less technical and also includes half of the non-physics material.

Thia allows us to transfer falling physics atudents at mid-year and let them finish the physics work on a less technical basis, but with additional material in the other flelds.

As in so many cases time limitations cut down on the amount of work accompliahed. More field work would be valuable but is difficult to arrange because of time restrictions and conflicts with other course work. school.

Our physical science has been a popular course in our

Our physical science course is offered as a terminal course in a sequence of courses consisting of general biolory, general chemistry, and sentor science. Those taking the course have, for the most part, followed a general curriculum and plan no further formal schooling. The class is ninety-five per cent boys.

As practiced in most public schools, we believe that general science or physical science has little value save for entertaining the student. We avoid this by stressing the importance of the study--not its entertatnment value.

This course is taught to a limited number of students taking vocational trade classes. 


\section{CHAPTER V}

\section{THE SUMMARY AND CONCLUSIONS}

The purpose of this study was (1) to determine the predominant characteristics, content, function, and place of the course In physical science in relation to the over-all science program, (2) to disclose some of the current practices found to be most applicable to the course, and (3) to determine the most important values and limitations of the course as it has currently been taught. This study was considered important, as very little of the literature available has pertained directly to what was actually being done by those who taught the course in physical science.

Printed questionnaires were sent to $217 \mathrm{high}$ schools and 8 school districts, with accompanying letters addressed to the heads of the department of science. The questionnaire was designed to ascertain (1) pertinent data about the schools, (2) current practices being used in the teaching of the course, and (3) predominant characteristics, content, function, and place of the course. One hundred and three questionnaires from twenty-four states and the District of Columbia were returned. The data for the gurvey were obtained from the eighty-seven of these schools which presently 
taught or had in the past taught the course in physical science. The enrollments of these schools varied from a low of 85 students to a high of over 4, 300 students, although the greatest number of schools had enrollments between 200 and 2,000 studenti.

\section{SUMMARY}

The characteristics, content, function, and place of the course.

In summarizing the characteristics and content of the high school course in physical science it was found that:

1. Most schools taught the course in the eleventh and twelfth grades, with a small percentage of schools offering it in the ninth and tenth grades.

2. The course was generally taught for a full year; although a few schools offered it for one semester, and one school offered a two-year course.

3. Although a small group of schools taught the course before World War II, the figures definitely indicated an increasing growth of the number of schools offering the course in the post-war years.

4. Fourteen different titles were indicated for the course, although Physical Science, or the similar title Physical Science Survey, was being used by the majority of the schools. 
5. The course content varied greatly, although nearly all of the schools included at least "some" chemistry and physics; in general, these subjects constituted the majority of the curriculum, with varying amounts of time spent on the other physical sciences. The mean per cent of time spent on each of the subject areas was as follows: astronomy, ten per cent; chemistry, twenty-three per cent; physics, thirty-five per cent; meteorology, sixteen per cent; and geology and physical geography, sixteen per cent.

The responses which concerned the function and place of the course were summarized as follows:

1. The course functioned in $\mathbf{8 3}$ per cent of the schools as a terminal course for non-sclence majors; it served in a small number of schools as a substitute for chemistry or physics; and it functioned in a few schools as a step in the sequence of courses to provide a background for further high school study in chemistry, physics, or other physical sclences. Thirty-five per cent of the schools indicated more than one of the above functions for the course.

2. Only fourteen per cent of the schools indicated that the course was required, and the majority of these schools indicated that it was required only if another science course was not taken 
to fulfill the science requirement for graduation.

3. In 60 per cent of the schools, the course was developed primarily to aid slow learners.

Current practices used in teaching the course.

The areas included in this study as current practices were (1) materials used in teaching the course; (2) activities used in conjunction with the course, such as (a) laboratory work, (b) field trips, (c) resource persons, (d) sctence hobbies, and (e) science projects; and practices used to (a) teach the scientific method and its application to everyday living. (b) build a scientific vocabulary, (c) develop open-mindedness, scientific curiosity, healthy skepticism, and sugtained critical thinking, and (d) develop an appreciation of science.

In summarizing the responses which pertained to materials used in teaching the course it was found that:

1. Most schools used a single textbook, although seventeen per cent of the schools reported the use of more than one or a set of texts, and nearly fifty per cent of the schools indicated the use of supplementary reading materials in one form or another.

2. The materials other than textbooks which were used included flims and filmstrips; the publications "Current Science and 
Aviation" and "Science Newsletter," pamphlets, booklets, brochures, and science magazines; reference books and additional textbooks; charts, pictures, globes, maps, and models; teaching aids from General Motora, General Electrlc, and other industrial concerns; and workbooks, laboratory manuals, and demonatration and laboratory equipment.

3. A large number of teachers indicated that difficulties had been encountered in securing adequate textbookg. The difficulties indicated were (1) a lack of good texts on the market from which to choose, (2) general administrative regulations for securing texts, (3) that no texts were avallable which suited the purposes of the individual courses, and (4) that texts were not keyed to the abllity levels of the students taking the course.

4. Nearly all of the schools reported that approprlate fllms and filmstrips were readlly available. Only two teachers indicated a lack of published film material, and a few teachers indicated difficulties in scheduling films at the destred times or were concerned with the expense involved in securing film material.

A summary of activities used in teaching the courae was as follcws:

1. Seventy-nine per cent of the schools were using more than one type of laboratory work in teaching the couree. In terms of 
total figures, ninety-five per cent of the schools were using teacher demonstrations, fifty-eight per cent were using student demonstrations, forty-six per cent were using occasional laboratory periods as needed, and eighteen per cent of the schools were using frequent or regularly scheduled laboratory periods. The combination most frequently indicated was occasional laboratory periods, student demonstrations, and teacher demonstrations; and the next most frequently mentioned combination was student and teacher demonstrations.

2. In regard to which type of laboratory work the teachers felt would be best suited to the course, many suggestions were given. The largest number of teachers felt that student participation in demonstrations and experiments would be of the most value, although it was indicated that in many schools the large class enrollments and/or a lack of adequate laboratory facilities made this practice impractical or impossible. A considerable number of teachers felt that teacher demonstration or student and teacher demonstration were most applicable to this course.

3. Nearly fifty per cent of the teachers used field trips in conjunction with the course. The number of trips taken varied from "zero to. one" to "elght to ten." The largest number of the field trips described were visits to manufacturir $r_{b}$ rants and 
industrial concerns; a considerable number were visits to science exhibits and scientific operations; and a small number were visits to public utilities and trips to observe geological formations.

4. Only thirty-seven per cent of the schools invited resource persons to visit the physical science class, although an additional small per cent of the schools indicated that persons from the sclentific flelds spoke occasionally or frequently in the all-school assemblies. Most of the schools who did invite resource persons to the class indicated that they had two or three persons a year, and they were generally persons from public services, industry, or scientific fields.

5. A variety of methods were used by the teachers to encourage interest in science hobbies. These included: (1) constant encouragement or emphasis and continuously making appropriate suggestions, (2) reading, (3) class discussions, (4) encouraging or requiring projects, and (5) science clubs. Twenty-six per cent of the teachers replied that little or nothing was done in this area.

6. Only twenty-nine per cent of the teachers required science projects, although most of the teachers encouraged this activity. Encouragement was given through (1) suggestions 
and help when needed, (2) encouraging the students to display their profects, (3) sclence clubs, (4) the use of demonstrations and films, and (5) giving special recognition and commendation. Sixty-seven per cent of the schools offered availability to the students of either local or state science fairs, shows, displays, or contests for science scholarships as ways of receiving recognition for their projects.

A summary was made of the additional practices used in teaching the course as follows:

1. Seventeen per cent of the teachers felt that the sctentific method and its application to everyday living could best be approached through activities such as (1) projects, (2) laboratory experiments and demonatrations, and (3) working out specific everyday problems which involved the use of the scientific method. Eleven per cent of the teachers approached this area through the use of class discussions and reports on material the students had read from the textbooks, periodicals, and newspapers; seven per cent of the teachers combined the use of reference materials and discusgions with activities; and thirty-two per cent of the teachers reported that they stressed this a spect throughout the duration of the course.

2. Over fifty-five per cent of the teachers placed a great deal of emphasis on the teaching of a scientific vocabulary. This was 
done in twenty per cent of the classes by (1) constantly calling attention to and defining all new terms which arose in the daily work either from the textbooks or other sources, (2) stressing the importance of their application, and (3) encouraging the students to always use correct terms in all oral and written work. It was done in fourteen per cent of the classes by encouraging the students to observe the correct usage of scientific terms in the textbooks, other reference books, periodicals, and newspapers; and eighteen per cent of the teachers had organized vocabulary training programs which tncluded regular or frequent drills, quizzes, or testa, and which often included practices from one or both of the above groups.

3. In regard to what was being done to develop open-mindedness, scientific curiosity, healthy skepticism, and sustained critical thinking, nineteen per cent of the teachers who replied to this question indicated that little could be done due to the grade level of the students or to the fact that their classes were composed primarily of slow learners who could not grasp these concepts. However, nearly fifty per cent of the teachers made attempts to approach these aspects. The most predominant practices used were (1) to encourage the students to do outside reading from books, magazines, periodicals, 
and newspaper articles on scientific material, current events, and new discoveries, (2) to hold class discussions, reports, or debates, and (3) to present problem-solving situations to the students.

4. Sixty per cent of the teachers indicated what was done to develop an appreciation of science. They approached this aspect through (1) activities, (2) stressing the idea that science is the basis for all progress, (3) stressing the historical study of science, the study of current science, or both, and/or (4) stressing the application of science to everyday living. The presominant practices used were (1) class discussions and reports, (2) the use of audio-visual materials, (3) supplementary reading, (4) projects, (5) student demonstrations and experiments, (6) field trips, and (7) giving concrete examples of practical applications.

The values and limitations of the course.

The values and limitations were ascertained from (1) the schools' responses concerning the college acceptance of the course In physical science in their areas, (2) the reasons given for having discontinued the course from the schools which had taken this action, and (3) additional comments from the persons who completed the questionnaires. 
The college acceptance aspect was summarized as follows:

1. Eighty-two per cent of the teachers responding to this question indicated that some, many, or all of the colleges in their areas accepted the course 28 a science requirement for entrance of non-science majors.

2. Thirty-nine per cent of the teachers responding to this question indicated that no colleges accepted the course as a science requirement for entrance of science majors. Thirty-six per cent of the teachers indicated that some colleges accepted the course as an entrance requirement for science majors, and a few Indicated that many or all of the colleges accepted the course for sclence majors.

Four limitations of the course in physical sclence were brought out in the reasons expressed for having discontinued it. They were

1. The course did not meet the college needs of the students.

2. The course had attracted students who were seeking only an easy credit.

3. The course was too general and limited to be effective.

4. There was a lack of adequately prepared persons to teach such a course.

Twenty-elght per cent of the comments received on the questionnaires pertained to values of the course in phystcal science. The most frequently indicated values were summarized as follows: 
1. The students gained from the course a broad, over-all viewpoint of science and its practical applications to their everyday living that such speciftc courses as chemistry or physics could not give.

2. The course was of value to slow learning students who could not do the work in chemistry or physica.

3. The course was of considerable value for students not going on to college.

Thirty-eight per cent of the comments received were in terms of limitations of the course. These comments were summartzed as follows:

1. The course was in a developmental stage and would require considerable reorganization.

2. The courge had become a "dumping ground" for over-age students, students who presented disciplinary problems, those seeking only an easy credit, and the slow learners.

3. Teachers are needed with more adequate training and more interest in the course.

\section{THE CONCLUSIONS}

The conclustons of the study were stated as follows:

1. The course in phyatcal science was generally taught for one year's duration to eleventh and twelfth grade students. 
2. There has been a definite increase in the number of courses in physical science since World War II.

3. The wide diversity in subject matter content for the course stlli persisted.

4. The course functioned predominantly as a terminal course for non-science majors.

5. The course was widely used to aid slow learners.

6. The physical science textbooks available have not proven to be entirely satisfactory and further research is needed in this area.

7. Those teaching this course have made extensive use of the supplementary materials available.

8. Teacher and atudent demonstrations were used extensively in conjunction with this course.

9. Field trips and projects were used frequently in teaching the course.

10. Considerable effort was made to develop a scientific vocabulary.

11. Colleges have generally accepted this course for entrance of non-science majors.

The position of the course in physical science has yet to be clearly defined. It is basically in a developmental stage and in need of continued reorganization. Because of this, some schools have 
become dissatisfied with the academic accomplishments of the students taking this course. Otten it has proved unattractive to the average or above average student and at times has become a "dumping ground" for the slow learner and the problem student. In addition, it has been difficult to procure teachers with broad training in all of the physical science fields and with the abllity to work with and understand the type of student most often attracted to this course. However, it was encouraging to note that the public schools are endeavoring to provide a course to enlarge the scientific background of the non-science student and give the student a broad, over-2ll view of the physical sciences and their applications to everyday living. 


\section{BIBLIOGRAPHY}

82531 
BIBLIOGRA PHY

The American Educational Catalog. New York: R. R. Bowker Company

Bowley, A. L. Elements of Statistics. London: P. S. King and Company, $1 \overline{820 .}$

Brooks, William O., and Ceorge R. Tracy. Modern Physical Science. New York: Henry Molt and Company, 1852.

Brown, H. Emmett. The Development of a Course in the Physical Sciences for the Lincoln School. New York: Teachers College, Bureau of Publications, 1939.

Erown, H. Emmett. "Trends in High School Courses in Integrated Physical Science," The Bulletin of the National Association of Secondary-School Principals, 37:83-91, January, 1953.

Carleton, Robert H. "The Acceptability of Physical Science as a College Entrance Unit." Science Education, 30:127-132, April, 1946.

"The Course of Physical Science," Science Education in American Schools, Forty-sixth Yearbook of the National Society for the Study of Education, Part I. Chicago, Illinois: University of Chicago Press, 1946.

tiby, G. S., C. L. Waugh, H. E. Welch, and B. H. Buckingharn. The Physical Sciences (Revised edition). New York: Ginn and Company.

Federal Security Agency, Office of Education. Biennial Survey of Education in the United States. Washington: United States Government Printing Office, 1950.

Grant, Charlotte. "A High School Teacher Looks at Science Education Objectives," The Bulletin of The National Association of Secondary-School Principals, 37: 16, January, 1953.

Heiss, William O., and Ellsworth S. Obourn, and Charles W. Hoffman, Modern Science Teaching (New York: Macmillan Company, 1950), 
Herriott, M. F., and Charles H. Nettels. "Functional Physical Science," Currtculum Journal, 13:362-365, April, 1944.

Hollinger, John A., and others. "Physical Science in Sentor High Schools," Science Education, 28:130-135, April, 1944.

Hogg, John C., Judson B. Cross, and Elbert P. Litile. Physical Sciences for High Schools. New York: D. Van Nostrand Company, Inc.

Johnson, Philip G. "Adaptions of the Physical Sciences to the Needs of Secondary School Pupils," American Journal of Physics. 15:480-483, November, 1947.

Johnson, Philip G. "Occurrence of Sctence Courses in American High Schools," The Bulletin of the National Association of Secondary-School Principals, $37 \overline{7: 23}$, January, 1953.

Johnson, Philip G. The Teaching of Science in Public High Schools. Federal Security Agency, Office of Education, Bulletin No. 9. Washington Government Printing Office, 1950.

Lowry, Nelson L. "Biology and Physical Science for Ninth-and Tenth-Grade Students, "Science Education, 35:71-73, March, 1951.

Miles, Vaden L. "A Determination of Principles and Experiments for an Integrated Course of Physical Science for High School," Science Education, 33:147-152, Narch and April, 19:9.

Morse, Stanley W. "High School Science Experiences of 506 NonScience Curricula College Students," Science Education, 34:117126, March, 1950.

Peterson, Shailer. "The Evaluation of a One-Year Course, the Fusion of Physics and Chemistry, with Other Physical Science Courses," Science Education, 29:255-264, December, 1945.

Physical Science Symposium. "Physical Science Today," The Science Teacher, 18:13-21, November, 1951.

Ratrick, G. L., and John G. Read. "Criteria for Evaluating a Secondary School Science Program," Educational Administration and Supervision, 36:306-315, May, 1950 . 
Robinson, Myra $G$. "The Contributions of a Fused Science Course to Ceneral Education," School Review, 54:215-221, April, 1946.

Tenney, Asa C. "A Fused Physical-Science Course," Sclence in General Education. New York: Appletom entury, 1838.

Watson, Donald R. "A Comparison of the Growth of Survey Courses in Physical Science in High Schools and in Colleges," Science Education, 24:14-20, January, 1940. 


\section{APPENDICES}


APPENDIX A

(The Questionnaire) 
A QUESTIONNAIRE SURVEYING

THE HIGH SCHOOL COURSE

IN PHYSICAL SCIENCE

Your name

Position

School

Location

Please Complete the Following or Circle the Appropriate Response.

1. How many tudents are enrolled in your school?

2. What grades are taught in your school?

3. a. Does your school now teach a course in physical science?

YES NO

b. If no, has your school taught this course in the past?

YES NO

c. What year was it first taught?

d. If this course has been discontinued in your school, please give some of the most important reasons why.

4. For which grade level is this course designed?

5. What is the duration of this course?

SEMESTER FULL YEAR Other 
6. What other science courses are offered by your $8 \mathrm{chool}$ ?

GENERAL SCIENCE

BIOLOGY

PHYSICS

CHEMIST R Y

Others

7. What is the exact title of the course in physical science taught in your school?

8 a. Please give the title and author of the physical science textbook you. now use.

b. What other types of teaching materials do you use?

c. What difficulties have arisen in securing adequate, up-to-date textbooks and other materials?

9. a. Is this course required by your school?

$$
\text { i. }
$$

YES NO

b. Is this course designed as a terminal course for non-science majors?

YES NO

c. Does this course substitute for chemistry or physics in your school's curriculum?

YES NO

d. Was this course primarily developed to aid slow learners?

YES NO

e. Was this course designed as a step in the sequence of courses to provide a background for further high school study in chemistry, physics, or other physical sciences?

YES NO 
10. How many of the colleges in your area accept this course as part of the science requirement for entrance of:

Non-Science

Majors?

ALL MANY SOME NONE

Science

Majors?

ALL MANY SOME NONE

11. About what percentage of time is used to explore the following subject areas?

Astronomy Physics

Chemistry Meteorology

Geology \& Physical Geography

12. a. How many field trips are taken in conjunction with this course?

b. Which field trips do you feel are most valuable?

13. What type of laboratory work is done in this course? (Check more than one if appropriate)

Frequent or regularly scheduled

laboratory periods

Occasional laboratory periods as needed or at the teacher's discretion

Student demonstrations

Teacher demonstrations

14. What do you feel would be the best type of laboratory experience for this course? 
15. a. How many resource persons are invited to the class during the course?

b. Which of these do you feel are most valuable?

16. What is done in teaching this course to encourage science hobbies?

17. a. Are student science projects required?

YES NO

b. What is done to stimulate student interest in science projects?

c. What opportunities are available to the students for displaying and receiving recognition for their projects? (For example, science fairs, science shows, etc.)

18. a. Are films on the appropriate subjects readil y available?

YES NO

b. If not, what difficulties arise in securing the proper films and film strips?

c. Which films and film strips have you found most valuable? 
19. 'What is done in conjunction with this course to accomplis $h$ the following?

a. The teaching of the scientific method and its application to every day living.

b. The building of a scientific vocabulary.

c. The development of open mindedness, s cientific curiosity, healthy skepticism, and sustained critical thinking. 
d. The development of an appreciation of science.

20. Additional information and comments you feel pertinent to this survey.

Thank you for filling out this questionnaire. Please return it in the enclosed self addressed envelope to:

Physical Science Survèy" Central Washington College of Education

Box 61

Ellensburg, Washington 


\section{APPENDIX B}

(The Letter Which Accompanied the Questionnaire) 
Head of the Department of Salence

Dear Sir:

Preliminary research indicates that your school may have taught or may now be teaching a course in physical science. As this course is a comparatively recent addition to, the high school science curriculum, most of the information av8liable is theoretical in nature and does not pertain to what is being done in the classroom. This survey was designed as an attempt to answer some of the questions which may arise concerming what is actually being done by those who teach the high school course in physical science.

The survey includes questions of general intormation and questions taken from sets of objectives for the teaching of high school science. It is hoped that. the results of this survey may be of some help to (I) administrators, supervisors, and others who are considering this course as an addition to their present science program, (2) teachers in the field who may be expected to teach the course in the future, and (3) teachers in training who wish to prepare themselves for teaching this course.

The enclosed questionnaire may be filled out by the head of the science department or by the physical science teacher. Although the last few questions may talre some additional time and effort, your cooperation in fijling out all the questions as completely as possible will. be very mich appreclated. Any additional infornetion which you feel would be of value may be written on the reverse side of this letter or on an additional sheet of paper and returned with the questionnaire in the stamped, self-addressed envelope.

Thank you for your help and cooperation. Sincerely,

Kenneth H. Johnson

Graduate Assistant 
APPENDIX C

(The Feminder Card) 


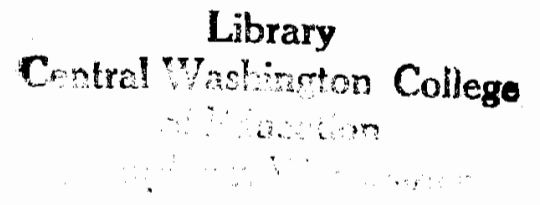

JUST A REMINDER:

A response to the PHYSICAL SCIENCE SURVEY sent to your school has not yet been roceived. Your cooperation in completing and returning it as soon as possible, if you have not already done so, will be appreciated.

Thank you rery much.

PHYSICAL SCIENCE SURVEY ĆWCE Box 61

Ellenoburg. Washington 